\title{
Origin of Critical Metals in Fe-Ni Laterites from the Balkan Peninsula: Opportunities and Environmental Risk
}

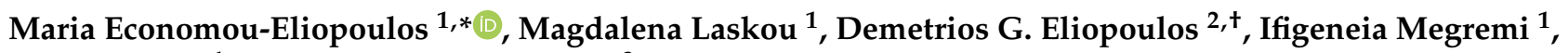 \\ Sofia Kalatha ${ }^{1}$ and George D. Eliopoulos ${ }^{3}$ \\ 1 Department of Geology and Geoenvironment, National and Kapodistrian University of Athens, 15784 Athens, \\ Greece; laskou@geol.uoa.gr (M.L.); megremi@geol.uoa.gr (I.M.); spkalatha@gmail.com (S.K.) \\ 2 Institute of Geology and Mineral Exploration (IGME), Olympic Village, 13677 Acharnae, Greece \\ 3 Department of Chemistry, University of Crete, 70013 Heraklion, Greece; chem1723@edu.chemistry.uoc.gr \\ * Correspondence: econom@geol.uoa.gr \\ † Demetrios passed away in April 2019.
}

Citation: Economou-Eliopoulos, M.; Laskou, M.; Eliopoulos, D.G.; Megremi, I.; Kalatha, S.; Eliopoulos, G.D. Origin of Critical Metals in Fe-Ni Laterites from the Balkan Peninsula: Opportunities and Environmental Risk. Minerals 2021, 11, 1009. https://doi.org/10.3390/ $\min 11091009$

\section{Academic Editors:}

Cristina Domènech and

Cristina Villanova-de-Benavent

Received: 4 August 2021

Accepted: 13 September 2021

Published: 16 September 2021

Publisher's Note: MDPI stays neutral with regard to jurisdictional claims in published maps and institutional affiliations.

Copyright: (C) 2021 by the authors Licensee MDPI, Basel, Switzerland. This article is an open access article distributed under the terms and conditions of the Creative Commons Attribution (CC BY) license (https:// creativecommons.org/licenses/by/ $4.0 /)$.

\begin{abstract}
As the global energy sector is expected to experience a gradual shift towards renewable energy sources, access to special metals in known resources is of growing concern within the EU and at a worldwide scale. This is a review on the Fe-Ni \pm Co-laterite deposits in the Balkan Peninsula, which are characterized by multistage weathering/redeposition and intense tectonic activities. The ICP-MS analyses of those laterites indicated that they are major natural sources of $\mathrm{Ni}$ and $\mathrm{Co}$, with ore grading from 0.21 to $3.5 \mathrm{wt} \% \mathrm{Ni}$ and 0.03 to $0.31 \mathrm{wt} \% \mathrm{Co}$, as well as a significant Sc content (average $55 \mathrm{mg} / \mathrm{kg}$ ). The SEM-EDS analyses revealed that fine $\mathrm{Fe}-$, $\mathrm{Ni}-$, $\mathrm{Co}-$, and $\mathrm{Mn}$-(hydr)oxides are dominant host minerals and that the enrichment in these elements is probably controlled by the post-formation evolution of initial ore redeposition. The paucity of rare earth element (REE) within the typical Fe-Ni laterite ore and the preferential occurrence of Co (up to $0.31 \mathrm{wt} \%$ ), REE content (up to $6000 \mathrm{mg} / \mathrm{kg} \Sigma \mathrm{REE}$ ), and REE-minerals along with Ni, Co, and Mn (asbolane and silicates) towards the lowermost part of the Lokris (C. Greece) laterite ore suggest that their deposition is controlled by epigenetic processes. The platinum-group element (PGE) content in those Fe-Ni laterites, reaching up to $88 \mu \mathrm{g} / \mathrm{kg}$ Pt and $26 \mu \mathrm{g} / \mathrm{kg}$ Pd (up to $186 \mu \mathrm{g} / \mathrm{kg}$ Pd in one sample), which is higher than those in the majority of chromite deposits associated with ophiolites, may indicate important weathering and PGE supergene accumulation. Therefore, the mineralogical and geochemical features of Fe-Ni laterites from the Balkan Peninsula provide evidence for potential sources of certain critical metals and insights to suitable processing and metallurgical methods. In addition, the contamination of soil by heavy metals and irrigation groundwater by toxic $\mathrm{Cr}(\mathrm{VI})$, coupled with relatively high $\mathrm{Cr}(\mathrm{VI})$ concentrations in water leachates for laterite samples, altered ultramafic rocks and soils neighboring the mining areas and point to a potential human health risk and call for integrated water-soil-plant investigations in the basins surrounding laterite mines.
\end{abstract}

Keywords: Fe-Ni-Co laterites; critical metals; REE; PGE; Cr(VI) contamination

\section{Introduction}

As gradual shift towards renewable energy sources on a global scale, access to particular raw materials or critical metals (CM), such as platinum-group elements (PGE), rare earth elements (REE), and scandium (Sc), with potential presence in known resources is a growing concern within the European Union (EU) and in a worldwide scale [1,2]. Although the production for these metals is mostly derived from magmatic deposits, volcanogenic massive sulfide (VMS) deposits, the black shale-hosted deposit in Finland and Sweden, and deposits of supergene origin associated with the release of major and trace elements from the alteration of related rocks [1,3-7], deposits of $\mathrm{Fe}-\mathrm{Ni} \pm \mathrm{Co}$ laterite may be a potential resource for critical metals as well $[8,9]$. Ni laterites contain about $60-70 \%$ of the world's nickel resources and account for about $40 \%$ of the world's nickel production, with 
the remainder coming from sulfide ores [10]. The $\mathrm{Ni}-\mathrm{Co}$ laterite deposits provide one of the two major natural sources of nickel and cobalt and became of economic importance with the recent increasing industrialization of developing countries [11]. The type of $\mathrm{Ni}-$ Co laterites developed by chemical weathering of ultramafic rocks with potential post redeposition enrichment of weathering products may occur above weathered bedrock. Among others, they have been described in the Philippines (Taganito/Adlay), in Western Australia (The Murrin Murrin deposit), in New Caledonia, Indonesia, and the Dominican Republic [11-13]. Recently, the $\mathrm{Fe}-\mathrm{Ni} \pm \mathrm{Co}$ type of laterites is an attractive research topic due to their large tonnage, easy exploitation (open pit mining), a significant development of a $\mathrm{Ni}$ and Co demand, and the technological innovations implemented by exploration companies [11,12]. With respect to known classifications, three mineralogical subtypes of $\mathrm{Fe}-\mathrm{Ni} \pm \mathrm{Co}$ laterite deposits are recognized: the oxide, hydrous $\mathrm{Mg}$-silicate, and clay types, with median $\mathrm{Ni}$ and Co grades, $1.14 \%$ and $0.09 \%$ of the oxide type, 1.44 and $0.06 \%$ for the $\mathrm{Mg}$ type, and 1.27 and $0.06 \%$ for the clay type [11,13]. The Fe-Ni laterite deposits in the Balkan Peninsula are associated with ophiolites, which represent a remnant of the Tethyan oceanic lithosphere, located in the Mirdita-Sub-Pelagonian and Pelagonian geotectonic zones [14]. They provide some $2-3 \%$ of the World's total Ni and include deposits in Serbia (Topola), in N. Macedonia, former F.Y.R.O.M. (Rzanovo), Albania (Bitincka, GouriPerjuegjiun, and Katjeli) and Greece (Lokris, C. Evia, Kastoria, Vermion, Paleochori, Edessa, Olympos) (Figure 1) [15-21].



Figure 1. Sketch map showing the Pelagonian (A), Sub-Pelagonian (B), and Axios (C) geotectonic zones in the Balkan Peninsula, and the distribution of ophiolites and the associated $\mathrm{Fe}-\mathrm{Ni} \pm \mathrm{Co}$ laterite deposits.

Furthermore, the weathering/alteration of laterite deposits and parent ultramafic rocks, mining, and large volumes of smelting residues (slag) are potential sources of environmental hazards for terrestrial and aquatic ecosystems, food quality, and socioeconomic problems $[1-4,10,11]$. An evaluation of the environmental risks associated with a possible exploitation of the deposits may contribute to the potential ways forward to protect soil and groundwater for human health and ecosystems. The present study focuses on the combination of $\mathrm{Ni}-\mathrm{Co}-\mathrm{Mn}$ mineral chemistry with geochemical characteristics of laterites from the Balkan Peninsula, which offer a variety of laterite types. The aim is the delineation 
of geochemical constraints as a contribution from the origin, genesis and exploration of critical metals (REE, PGE, $\mathrm{Co}, \mathrm{Sc}$ ) in laterites to the environmental impact from mining and plant processes of laterite ores.

\section{Geological Outline of Fe-Ni \pm Co Deposits and Occurrences in the Balkan Peninsula}

Based on national mineral resource agencies, approximately 500 Co-bearing deposits and occurrences have been identified in 25 countries in Europe [9]. The measured mineral resources in Greece are 220,000,000 tons [9,11]. The Ržanovo deposit, located close to the contact between the Axios zone and the Pelagonian massif, is one of the largest $\mathrm{Fe}-\mathrm{Ni}$ \pm Co deposits in the Axios zone [20]. In general, large Fe-Ni-Co laterite deposits, which have been exploited for many years, are mainly related to the extensive lateritization of ultramafic ophiolites in the Balkan Peninsula (Shebenik-Pogradec Massif at the central and southern part of the Mirdita ophiolites-Sub-Pelagonian and Pelagonian geotectonic zones) into Greece and by extension the Anatolides zone of western Turkey [20,22]. Major deposits show a complete weathering profile that comprises: (1) a lower zone of saprolitized peridotite with or without partially weathered core stones; (2) a transition zone which may be dominated by quartz or smectite clays; (3) a ferruginous saprolitic limonite zone; (4) a recrystallized and locally transported limonite zone; and (5) a goethite-hematite zone [23]. Although Fe-Ni \pm Co laterites in the Balkan Peninsula, related to Upper Jurassic-Lower Cretaceous serpentinized ultramafic ophiolites, may be partially preserved in situ, they are mostly allochthonous, redeposited as marine sediments, and buried by later sedimentary rocks [22]. The laterite ores have commonly been transported and redeposited either onto peridotites, such as at Kastoria, W. Vermion, and Palaiochori (Greece), Bitincka and Guri-Pergjegjum (Albania), or onto limestones, such as at Lokris (Aghios Ioannis), Katjeli (Albania) (Figures 1 and 2A). Those laterite deposits are often overlain by a sequence of mudstone, limestones, and organic carbon-rich mudstones, which have been attributed to a stagnant reducing marine environment during tectonic down warping [15]. In particular, the Katjeli Fe-Ni deposit lies on karstified Jurassic limestone, and it is conformably overlain by a Tertiary series consisting of small beds of lignite and sandstone intercalation and molasses. The exploited ores have been reworked due to repeated marine transgression and regression, deposited in a shallow marine environment, and affected by thrust faulting $[15,17,22,24]$. They can be divided into those which are unconformably overlain by Early Eocene shallow marine sediments, such as the Kastoria and Katjeli deposits in the Balkan Peninsula, and those overlain by Cretaceous limestones, such as the Lokris $[15,17]$. Specifically, the Kastoria Fe-Ni deposit is located in northern Greece (Figure 1), NNW of Kastoria town, is developed on Upper Jurassic-Lower Cretaceous serpentinized ultramafic ophiolites of the Mirdita-Sub-Pelagonian zone, and is overlain by Tertiary molasses. A goethite zone, 5-m thick, consisting mainly of goethite and hematite overlies a weathering crust $[18,25]$. At the W. Vermion (Profitis Elias), ophiolites are mainly comprised of large peridotite masses of harzburgite, dunite, and orthopyroxenedunite. The weathering crust is overlain by a highly silicified zone, while the ore is pelitic at its lowest part and becomes pisolitic towards the top. The Fe-Ni ore is mainly composed of goethite, hematite, Ni-bearing chlorite, quartz, calcite, and chromite. Talc is common in the lowest part of the ore, while illite is dominant in its upper part. In a distance of less than $1 \mathrm{~km}$ north of the Profitis Elias Ni laterite deposit, the Parhari deposit of bauxite laterite is located in an area where mafic rocks (diabases) are the dominant rock types [18]. More attention is paid to the Lokris (Aghios Ioannis) Fe-Ni laterite deposits (Figure 2) of allochthonous origin because of the association of $\mathrm{Fe}-\mathrm{Ni}$ ore with the bauxite laterite at the Nissi-Patitira location, and the relatively high contents of critical metals $[22,24,26]$. 


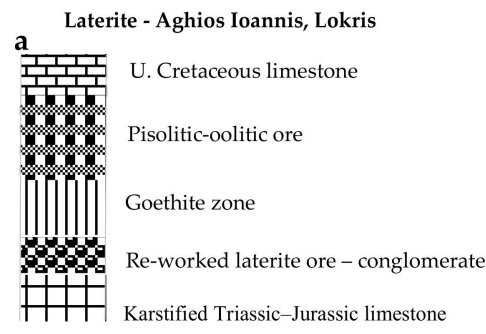

Bauxite laterite - Nissi, Lokris

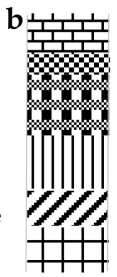

U. Cretaceous limestone

Re-worked laterite ore pyrite-bearing

Pisolitic-oolitic ore

Goethite zone

Re-worked laterite ore - Clay zone, ( $\mathrm{Co}, \mathrm{Mn}, \mathrm{Ni}, \mathrm{REE})$-elevated contents

Karstified Triassic-Jurassic limestone

W. Vermion-Profitis Elias

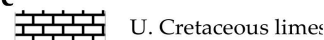

Kasroria
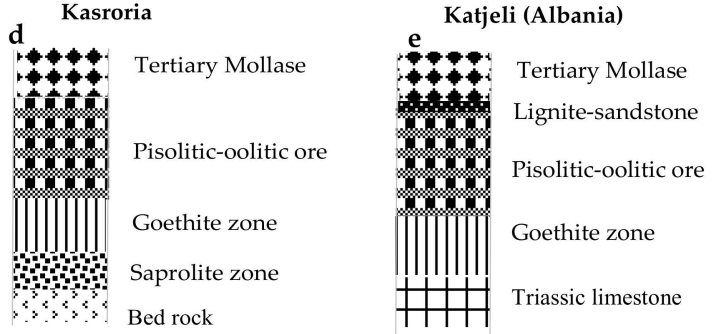

Bitincka \& Guri Pergiegjum (Albania)

Edessa

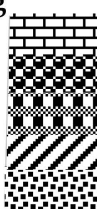

Cretaceous limestone

Conglomerate

Metamorphosed pisolitic-oolitic ore

Red silcrete

Altered harzburgite

Cretaceous limestone

Conglomerate

Metamorphosed pisolitic-oolitic ore

Altered harzburgite

(A)

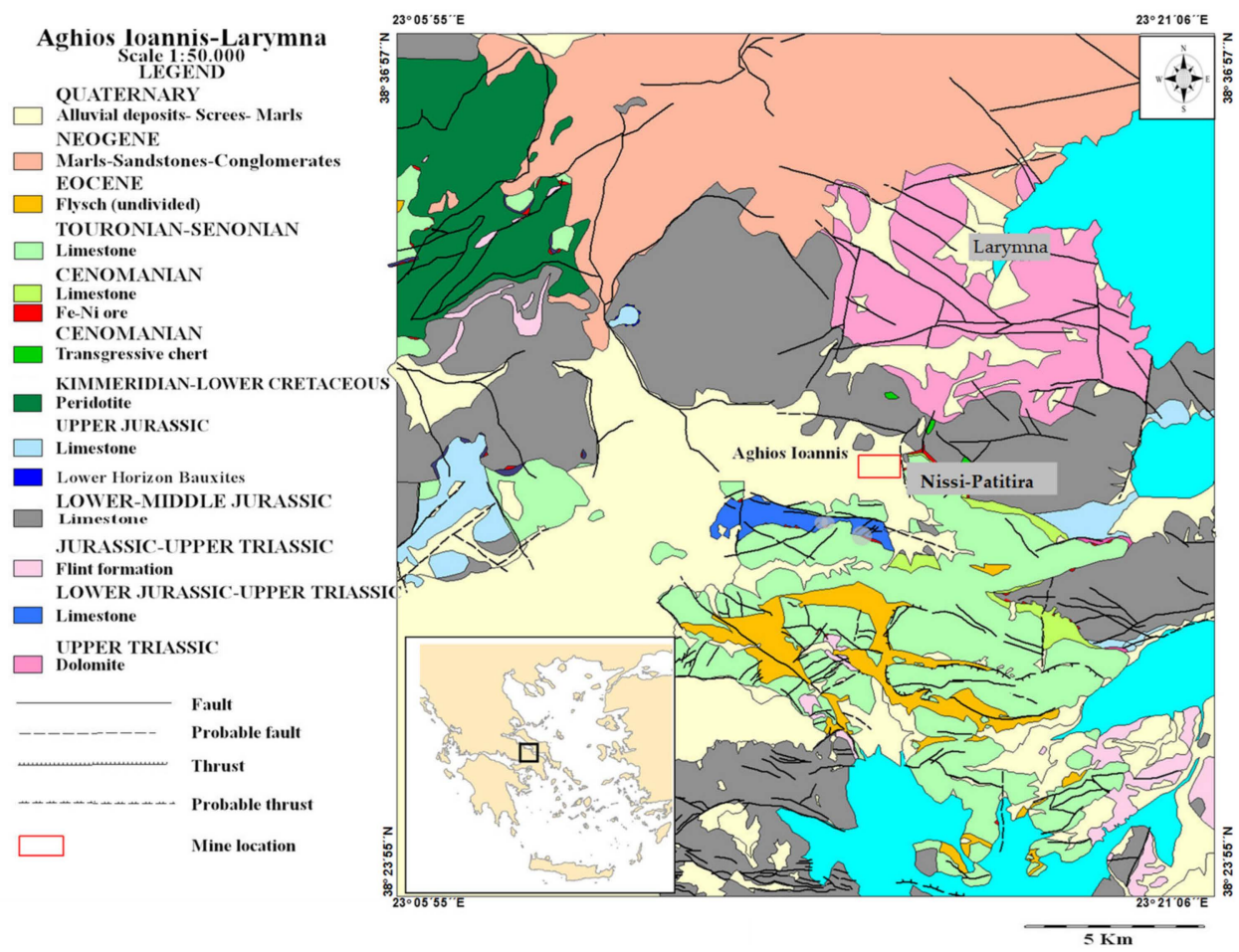

(B)

Figure 2. (A) Schematic stratigraphic sections of the most representative laterite deposits in the Balkan Peninsula. (B) Simplified geological map, after LARCO GMM (General Mining and metallurgical Company), cited in ProMine Project [27] showing the location of the main $\mathrm{Fe}-\mathrm{Ni}$ laterite deposits at Lokris (Aghios Ioannis).

Small $(1 \mathrm{~m} \times 15 \mathrm{~m})$ lens-like Fe-Ni occurrences, metamorphosed to amphibolite facies (probably erosional remnants of redeposited laterites), are found in the E. Vermion, Edessa, Olympos, and Skyros islands of Greece (Figures 1 and 2A) and are overlain by 
Cretaceous limestones [19]. The dismembered ophiolite masses of Upper Jurassic-Lower Cretaceous age, which consist of mainly serpentinized harzburgite and, to a lesser extent, crustal magmatic rocks (pyroxenites and gabbros), outcrop along the eastern margin of the Pelagonian massif [28]. Due to intense tectonism, the Fe-Ni laterite occurrences are often entirely enclosed within serpentinized harzburgites [19].

\section{Methods of Investigation}

Due to the heterogeneous character of most Ni laterite deposits, samples of a minimum $2 \mathrm{~kg}$ weight were collected from surface exposures. Although the analytical methods applied for the determination of major and trace elements in rocks, laterite ores, groundwater, and water leachates, including $\mathrm{Cr}$ stable isotopes and As speciation, is provided in the relative publications [29-31], a brief outline is given here. Two samples of metallurgical residue (slag samples, Slag96 and Slag14) from the Larymna plant, kindly provided by the mining company GMM LARCO (March 1996 and November 2014, respectively), and representative samples of ultramafic altered rocks were analyzed. Major and trace elements were determined by atomic absorption at the Institute of Geology and Mineral Exploration, Greece, and minor and trace elements were obtained by Inductively Coupled Plasma Mass Spectrometry (ICP-MS) analysis, after multi-acid digestion $\left(\mathrm{HNO}_{3}-\mathrm{HClO}_{4}-\mathrm{HF}-\mathrm{HCl}\right)$ at the ACME Laboratories Ltd., Vancouver, BC, Canada. Platinum-group element (PGE) analyses were carried out using the Ni-sulfide fire-assay pre-concentration technique, with the nickel fire-assay technique from large (30 g) samples at Genalysis Laboratory Services, Perth, Australia. This method allows for complete dissolution of samples. The detection limits were $1 \mathrm{ppb}$ for Pd, $10 \mathrm{ppb}$ for Pt, and 5 ppb Au. CDN-PGMS-23 was used as standard.

Representative surface (up to $20 \mathrm{~cm}$ ) soil samples from the rhizosphere of plants and corresponding plants/crops covering some sites surrounding laterite deposits have been analyzed by inductively coupled plasma mass spectroscopy (ICP/MS) after aqua regia digestion at ACME Laboratories Ltd., Vancouver, BC, Canada.

A series of batch leaching experiments have been carried out, using natural water in order to study the long-term leaching responses of $\mathrm{Cr}$ under atmospheric conditions [31]. For these experiments, $20 \mathrm{~g}$ of a crushed ore, metallurgical residue (slag), rock, or soil sample and $150 \mathrm{~mL}$ of natural water were transferred in a $200 \mathrm{~mL}$ Erlenmeyer flask at room temperature. The reaction flask was shaken at approximately $120 \mathrm{rpm}$ by a reciprocal shaker for 5 weeks. After the period of shaking, the slurries were filtered through a $0.45 \mu \mathrm{m}$ polyamide membrane filter. Furthermore, following the same methodology, except the shaker time, which was $24 \mathrm{~h}$ in this case, water leaching experiments were carried out in the present study.

Since oxidative weathering of Cr-bearing ultramafic rocks facilitate the oxidation of $\mathrm{Cr}$ (III) into water-soluble $\mathrm{Cr}(\mathrm{VI})$ and back again, the chromium isotopes have been applied in the investigation of contaminated groundwater and water leachates. Water and water leachates in an appropriate amount to have approximately $1 \mu \mathrm{g}$ of $\mathrm{Cr}_{\text {total }}$ were used for the determination of the $\mathrm{Cr}$ isotope composition following the method described by [29]. Both $\mathrm{Cr}$ concentrations and isotope ratios were analyzed using an IsotopX/GV IsoProbe $T$ thermal ionization mass spectrometer (TIMS) equipped with eight Faraday cups at the University of Copenhagen, Denmark. Four $\mathrm{Cr}$ beams $\left({ }^{50} \mathrm{Cr}+,{ }^{52} \mathrm{Cr}+,{ }^{53} \mathrm{Cr}+\right.$, and $\left.{ }^{54} \mathrm{Cr}+\right)$ were analyzed simultaneously with ${ }^{49} \mathrm{Ti}+,{ }^{51} \mathrm{~V}+$, and ${ }^{56} \mathrm{Fe}+$ beams, which were used to monitor interfering ions. The final isotope composition of a sample was determined as the average of the repeated analyses and reported relative to the certified SRM 979 standard as follows: $\delta^{53} \mathrm{Cr}(\%)=\left[\left({ }^{53} \mathrm{Cr} /{ }^{52} \mathrm{Cr}_{\text {sample }} /{ }^{53} \mathrm{Cr} /{ }^{52} \mathrm{CrSRM} \mathrm{M}_{99}\right)-1\right] \times 1000$. The raw data were corrected for naturally and instrumentally induced isotope fractionation using the double spike routine. To assess the precision of the analyses, a double spike-treated, certified standard reference material (NIST SRM979) was used.

A representative ore sample from the Nissi (Lokris) bauxite laterite deposit with remarkably high As content ( $350 \mathrm{mg} / \mathrm{kg}$ in bulk) was investigated by Synchrotron Radiation (SR). The SR micro-X-ray Fluorescence ( $\mu$-XRF) elemental mapping and micro-X-ray 
Absorption Fine Structure ( $\mu$-XAFS) spectra were both obtained in the X-ray beamline of the Laboratory for Environmental Studies (SUL-X) of the ANKA Synchrotron Radiation Facility (Karlsruhe Institute of Technology/KIT, Karlsruhe, Germany). For this purpose, solid fragments of the ore were embedded into resin and polished, whereas powders of reference minerals and compounds were pressed with cellulose to pellets. The SR $\mu$-XRF elemental maps and the As K-edge of the $\mu$-XAFS spectra revealed that As is exclusively correlated to $\mathrm{Fe}$, occurring as $\mathrm{As}^{5+}$ in the form of arsenate anions $\left(\mathrm{AsO}_{4}{ }^{3-}\right)$ [30].

Thin polished sections of $\mathrm{Fe}-\mathrm{Ni}$ laterites were investigated using a reflected light microscope, a scanning electron microscope (SEM), and energy dispersive spectroscopy (EDS). The SEM-EDS semi-quantitative analyses were carried out at the Department of Geology and Geoenvironmemt, National and Kapodistrian University of Athens (NKUA), using a JEOL JSM 5600 SEM (JEOL, Tokyo, Japan), equipped with the ISIS 300 OXFORD automated energy dispersive X-ray analysis system. Analytical conditions were $20 \mathrm{kV}$ accelerating voltage, $0.5 \mathrm{nA}$ beam current.

\section{Mineralogical Characteristic Features}

The texture characteristics of $\mathrm{Fe}-\mathrm{Ni} \pm \mathrm{Co}$ ores from the Balkan Peninsula reflect a multistage evolution of the mineralogy and mineral chemistry of the mineralization. Specifically, the Lokris $\mathrm{Fe}-\mathrm{Ni} \pm$ Co laterite deposits are mostly composed of goethite, limonite, hematite, Ni-bearing chlorite, Fe-chlorite, rutile, quartz, calcite, and chromite, while $\mathrm{AlOOH}$ polymorphs boehmite and diaspore are dominant minerals in the bauxite laterite; gibbsite, illite, kaolinite, montmorillonite, smectite, takovite, and $\mathrm{Ni}-\mathrm{Co}$ lithiophorite $(13 \mathrm{wt} \% \mathrm{Ni}$ and $9.2 \mathrm{wt} \% \mathrm{Co})$ replaced commonly by asbolane, manganomelane (6.2 $\mathrm{wt} \%$ $\mathrm{Ni}$ and $4.9 \mathrm{wt} \% \mathrm{Co}$ ), halloysite, and $\mathrm{Al}-\mathrm{Ni}-\mathrm{Co}-\mathrm{Mn}$ silicates are more abundant towards fractures and the lowest parts of the deposit $[15,17,18,24-26]$. A characteristic feature of the transitional zone between the overlying sequence of limestones and the carbonate basement of the laterite ores and organic carbon-rich mudstones is the presence of organic matter (Figure 3c,d) [24]. In addition, the lowermost part of the Lokris bauxite laterite deposit lying on karstified Jurassic limestone is characterized by the presence of abundant rare earth minerals (Figure $3 \mathrm{e}, \mathrm{f}$ ), such as authigenic (hydroxyl)bastnaesite-(Nd) and $(\mathrm{La}, \mathrm{Nd}, \mathrm{Y})$-bastnaesite, [26,29]. The Kastoria laterites, overlying a weathering crust, are composed of a pelitic matrix (goethite, hematite), clastic grains of quartz and chromite, as well as silicates (Fe-serpentine, talc), carbonates (calcite, siderite) and Mn-oxides (pyrolusite, lithiophorite), occurring as more than one type: rounded fragments of goethite occur in a subsequently formed matrix of ( $\mathrm{Fe}, \mathrm{Mn}, \mathrm{Ni})$-hydrous oxides associated with detrital quartz and chromite, while siderite and calcite cross-cut all previous formations (Figure 3g,h). Fine-grained goethite, growing over the vestiges of microorganism cells (Figure 3i) suggests the involvement of microorganisms in the deposition of goethite [24,26]. 


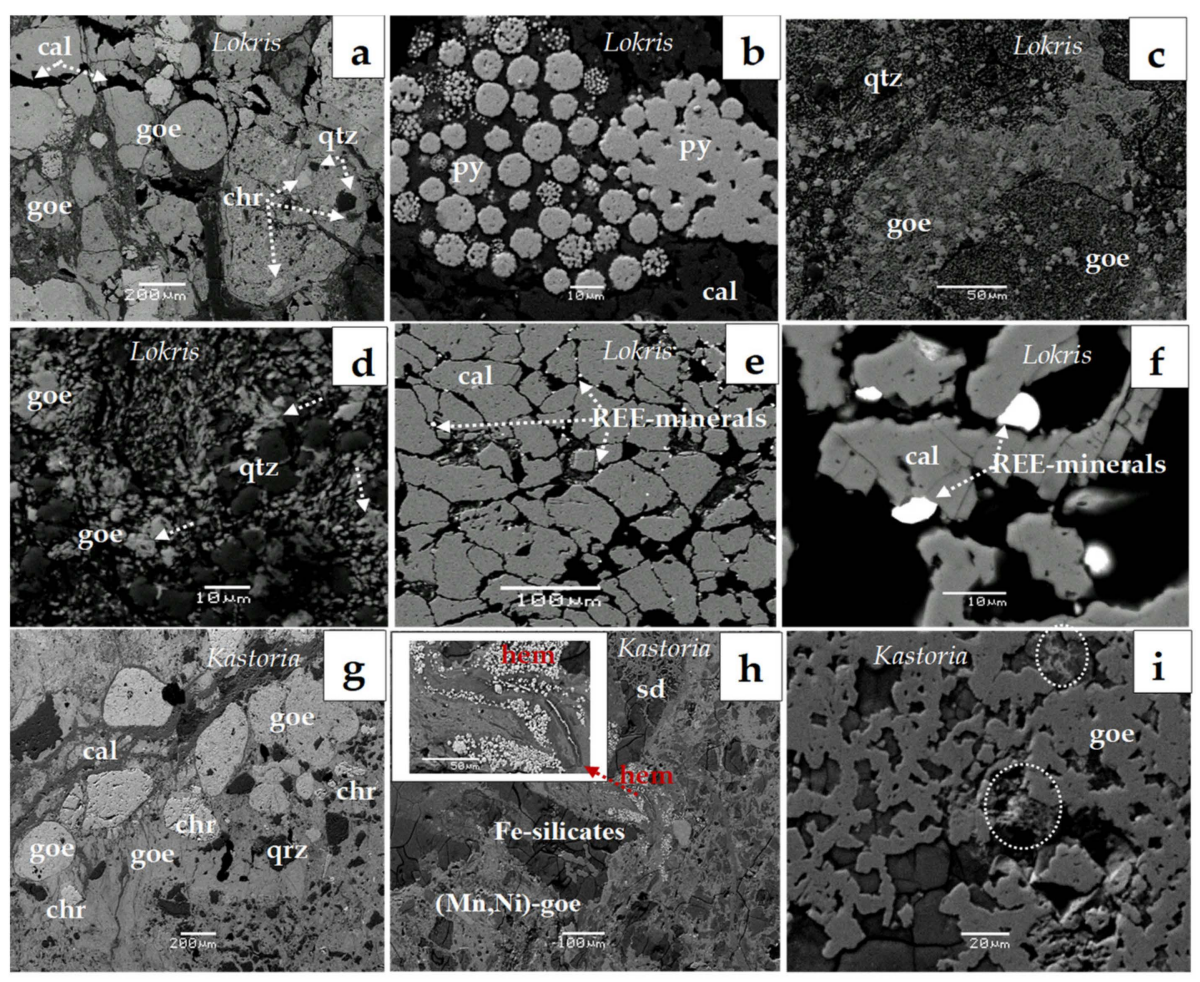

Figure 3. Selected back scattered electron (BSE) images from the Lokris and Kastoria laterites. A general overview from Lokris (a); the transitional zone between ore and overlying limestone showing neoformed clusters of framboidal pyrite with fine crystals at the contour of early framboidal pyrite (b); isolated and aggregates of bacteriomorphic goethite (goe) associated with quartz (qtz) (c,d) and REE-minerals (e,f) from the contact of the lowest part of the Nissi-Patitira deposit with the carbonate basement. Similarly, from the Kastoria Fe-Ni laterites showing different morphologies: Rounded fragments of goethite in a matrix of $(\mathrm{Mn}, \mathrm{Ni})$-goethite with goethite fragments of an earlier stage, detrital quartz, and chromite (g); close-up view of morphology of fine-grained hematite crosscutting earlier mineral phases (h); Mn-bearing siderite cutting all previous phases (h) and neo-formed goethite growing over microorganism cells (i). Abbreviations: goe = goethite; chr = chromite; py = pyrite; qtz = quartz; $c a l=$ calcite; $s d=$ siderite; hem = hematite; REE = Rare Earth Elements .

In addition, a salient feature of the Nissi-Patitira deposit at Lokris is the existence of transitional zones between a typical brown-red laterite ore, gradually grading to greywhite, grey-black, pinkish-white, and pale green zones (Figure 4a), as well as different goethite morphologies, with sub-micron spherulitic aggregates being the dominant microtextures (Figure $4 \mathrm{~b}-\mathrm{f}$ ). The occurrence of As-bearing bacteriomorphic goethite in samples with significant organic matter and the presence of $\mathrm{C}, \mathrm{N}, \mathrm{Fe}, \mathrm{Al}, \mathrm{K}, \mathrm{Si}, \mathrm{Ca}, \mathrm{Mn}$, and $\mathrm{Ni}$ in goethite, probably due to the presence of microorganisms, has been emphasized in previous studies [24,26]. 

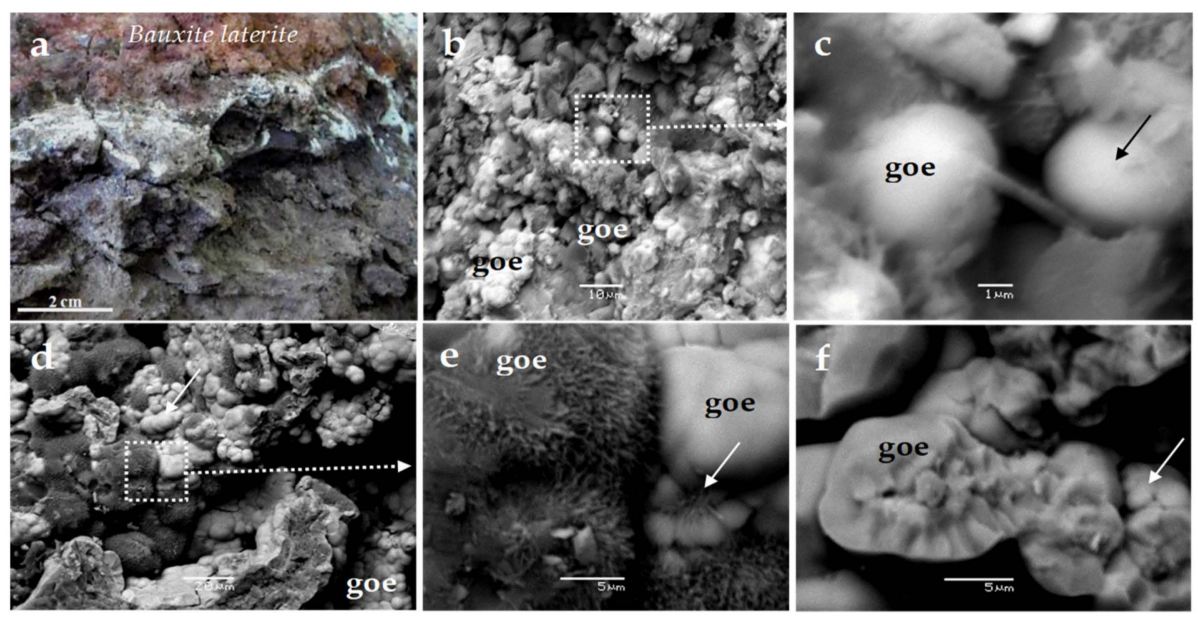

Figure 4. Field photograph (a) and BSE images (b-f) from unpolished parts of the Nissi-Patitira bauxite laterite ore. Highly tectonized reddish to deep red laterite gradually grading to gray, pinkish white, and pale green laterite ores along fractures and towards the carbonate basement limestones (a); goethite (goe) of different morphologies, with sub-micron spherulitic aggregates being the dominant microtextures (b-f); close-up view morphology of goethite $(\mathbf{c}, \mathbf{e})$ of the $(\mathbf{b}, \mathbf{d})$ corresponding, resembling bacterial cells coated by goethite (black and white arrows).

The groundmass of pisolitic and pelitomorphic ore in the Palaiochori and Katjeli deposits is fine grained, and it is mainly composed of iron oxides (goethite, magnetite, and hematite), clastic grains of chromite, quartz, Fe-chlorite (chamosite), calcite, Mn-bearing siderite, and Mn-oxides (pyrolusite) (Figure 4) [19]. Chromite grains are present in a relatively small proportion, whereas the pisolitic ore overlies the pelitomorphic ore [32] The occurrence of fossilized organic matter and different morphologies of goethite and/or carbonate minerals (siderite) are common in the Lokris, Kastoria, Palaiochori, Katjeli, and other deposits (Figures 3 and 5). The occurrence of chromite grains, inherited from the parent ophiolitic rocks, is a common feature of all Fe-Ni laterite ores and bauxite-laterites. They usually show a cataclastic texture, cemented by magnetite, or occur as chromite cores surrounded by a zone of Fe chromite, showing a gradual decrease of $\mathrm{Cr}, \mathrm{Al}$, and $\mathrm{Mg}$ as Fe increases outward from the core $[33,34]$. However, the alteration zone along cracks and peripheral parts of chromite from the Palaiochori and Katjeli deposits is very limited, and it is commonly darker in the BSE images (Figure 5c,e,f). A small amount of apatite is also present in the ores from Edessa (Figure $5 \mathrm{~g}$ ), while the presence of organic matter is common in Palaiochori and Katjeli deposits (Figure 5a,b,d).

The Fe-Ni ore in the W. Vermion is mainly comprised of goethite, hematite, Ni-bearing chlorite, quartz, calcite, and chromite. Talc is common in the lowest part of the deposit, while illite is dominant in its upper parts. Although the majority of the W. Vermion laterites are classified as Fe-Ni-Co laterites, bauxite-laterite has been located lying on serpentinized peridotites, at the Parchari area, in a distance of less than $1 \mathrm{~km}$ north of the Profitis Ilias Ni laterite deposit [18]. The bauxite laterite ore is mainly comprised of goethite, hematite, boehmite, Ni-Fe chlorite, illite, quartz, calcite, chromite, rutile, and small amounts of pyrite [18]. Apart from the dominant peridotites, mafic rocks (diabases) are also present in the Parchari area. 


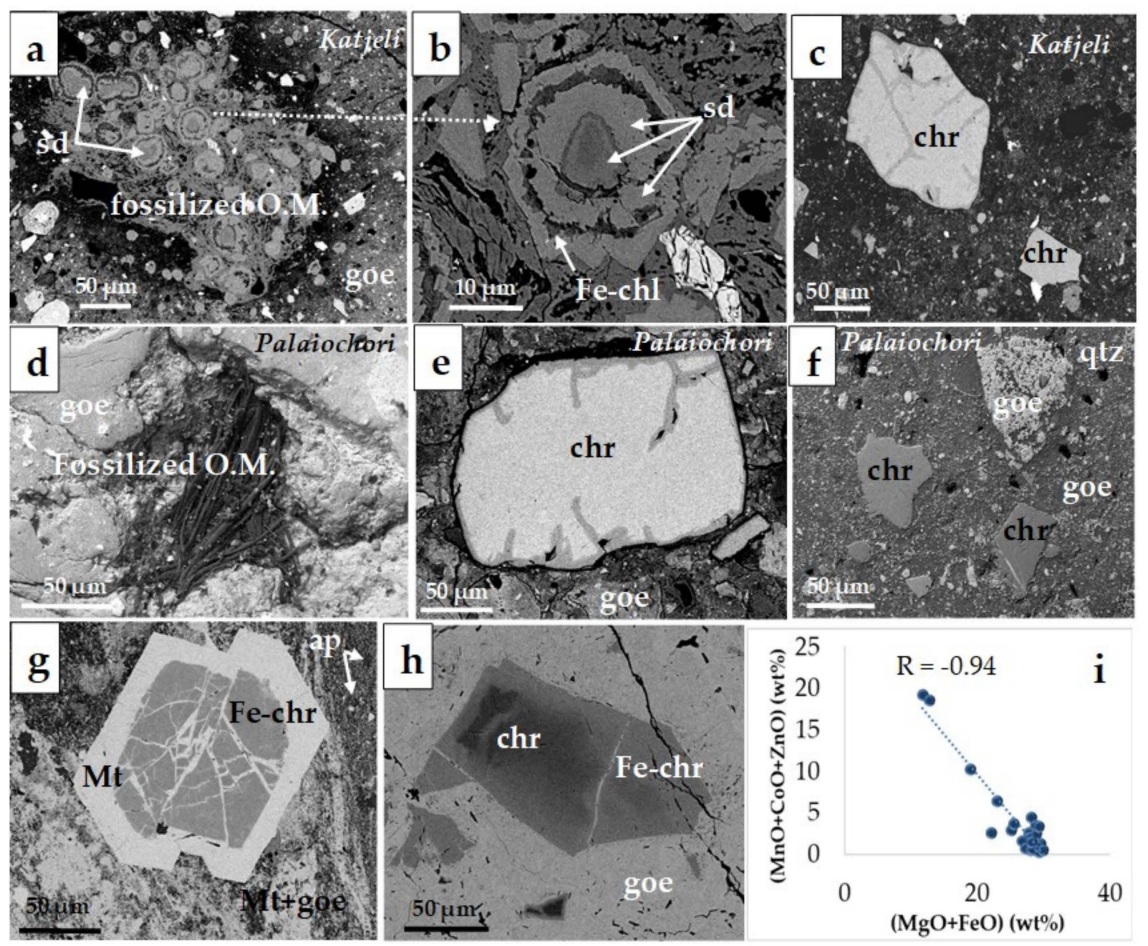

Figure 5. Selected BSE images showing fossilized organic matter and different morphological forms of goethite and/or siderite in Fe-Ni laterite ore from the Palaiochori and Katjeli deposits (a,b,d); very limited alteration zone along cracks and peripheral parts of chromite from the Palaiochori and Katjeli deposits (c,e,f); apatite in the ores from Edessa (g); magnetite and Fe-chromite surrounding chromite cores $(\mathbf{g}, \mathbf{h})$; a negative correlation between $(\mathrm{MnO}+\mathrm{CoO}+\mathrm{ZnO})$ content versus $(\mathrm{FeO}+\mathrm{MgO})$ content (i) data from [19]. Abbreviations: ap = apatite; Fe-chl = Fe-chlorite; O.M. = organic matter; $\mathrm{mt}=$ magnetite; as in Figure 3.

Most Fe-Ni \pm Co deposits are dominated by Fe-oxyhydroxides as the main nickel carrier, while the Mn-oxides are commonly enriched in $\mathrm{Co}$ and $\mathrm{Ni}$, and zoned chromite grains may contain $\mathrm{Mn}, \mathrm{Co}$, and $\mathrm{Zn}$ as well [19]. A common feature of the E. Vermion, Olympos, Edessa, and Skyros small laterite occurrences, which are found on serpentinized harzburgites, is the gradual increase of $\mathrm{Mn}, \mathrm{Co}$, and $\mathrm{Zn}$ outwards of the chromite, attaining the greatest values at the periphery of chromite cores and in the Fe-chromite, reaching values up to 13.0, 4.1 and $2.1 \mathrm{wt} \%$, respectively, and dropping off to negligible values in magnetite, as is exemplified by the plot of $(\mathrm{MnO}+\mathrm{CoO}+\mathrm{ZnO})$ versus $(\mathrm{MgO}+\mathrm{FeO})$ content and the strong negative correlation between them (Figure 5i) [19].

At the area of E. Vermio, there is abundant garnet (grossular) and calcite, while $\mathrm{Ni}$ is mainly hosted in chlorite, serpentine, and theophrastite (Figure 6a), the latter containing $80 \mathrm{wt} \% \mathrm{NiO}$ [35]. A (Co,Mn,Ni)-hydroxide with a wide compositional range occurs in a spatial association with theophrastite and organic matter (Figure $6 \mathrm{a}, \mathrm{b}, \mathrm{c}$ ). Hydroxides dominated by $\mathrm{Co}$, occur towards the central parts of the concentring development, while the peripheral parts are dominated by Mn (Figures $6 \mathrm{c}-\mathrm{f}$ and 7 , Table 1 ). The association of $(\mathrm{Co}, \mathrm{Mn}, \mathrm{Ni})(\mathrm{OH})_{2}$ and theophrastite with silicate minerals (mostly Ni-serpentine), garnet, and magnetite, all cross-cutting earlier deformation events (Figure 6), may have a common origin in space. The theophrastite coexists with magnetite and frequently encloses tiny grains of magnetite, both showing an orientation parallel to the general direction of the schistosity (Figure 6a). 


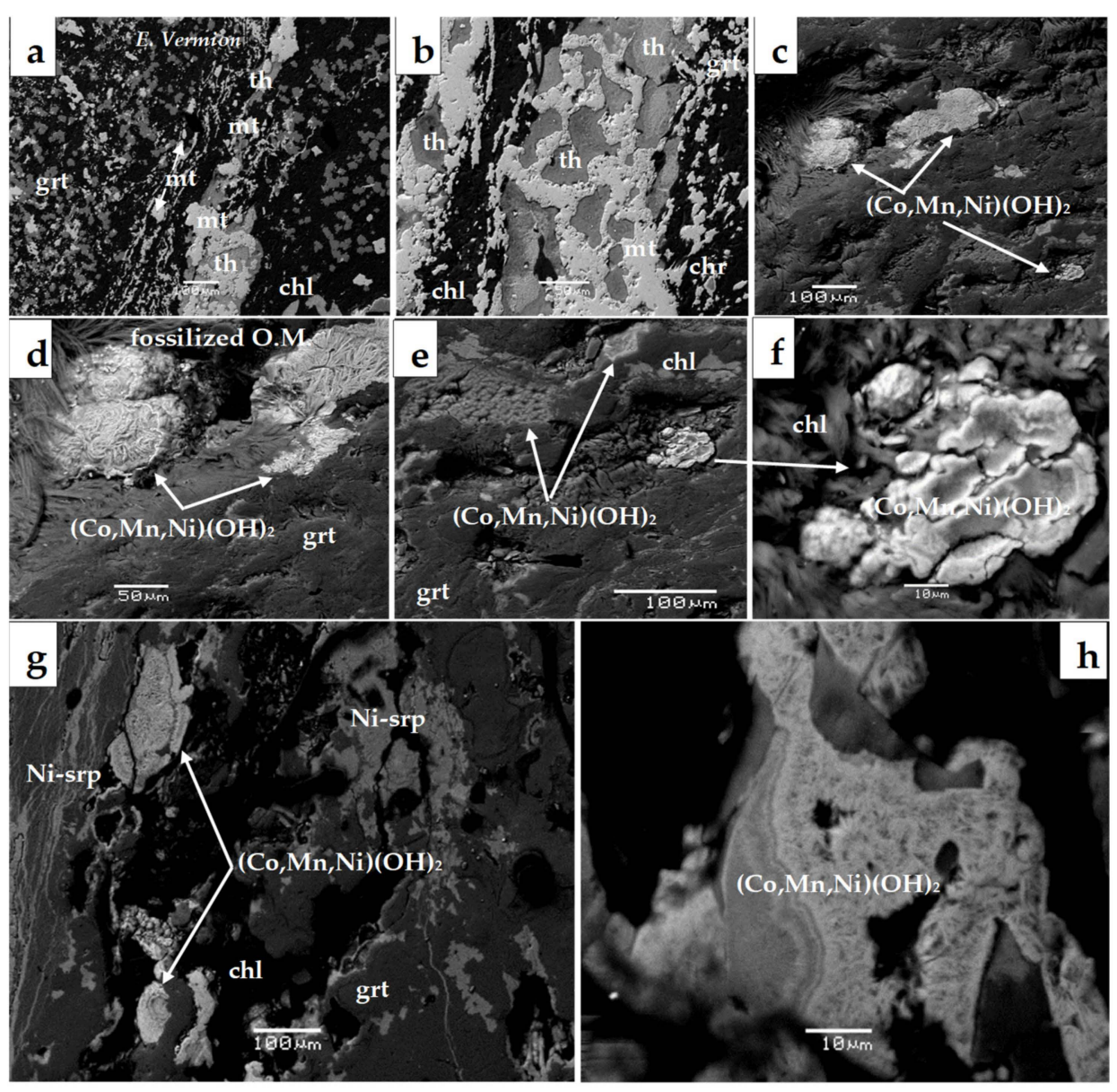

Figure 6. BSE images of metamorphosed Fe-Ni laterites from E. Vermion. Theophrastite associated with magnetite and garnet, in the form of crosscutting veinlets (a); the (Co-Mn-Ni) $(\mathrm{OH})_{2}$ associated with organic matter (O.M.) in a matrix dominated by garnet, well observed in unpolished parts of the studied sections $(\mathbf{b}, \mathbf{c})$; close-up view morphology of $(\mathrm{Co}-\mathrm{Mn}-\mathrm{Ni})(\mathrm{OH})_{2}(\mathbf{d}-\mathbf{h})$, showing successive thin layers, composed by fine fibrous crystals (h). Abbreviations O.M. = organic matter; $\mathrm{mt}=$ magnetite; grt $=$ garnet; $\mathrm{chl}=$ chlorite; $\mathrm{Ni}$-srp $=$ Ni-serpentine.

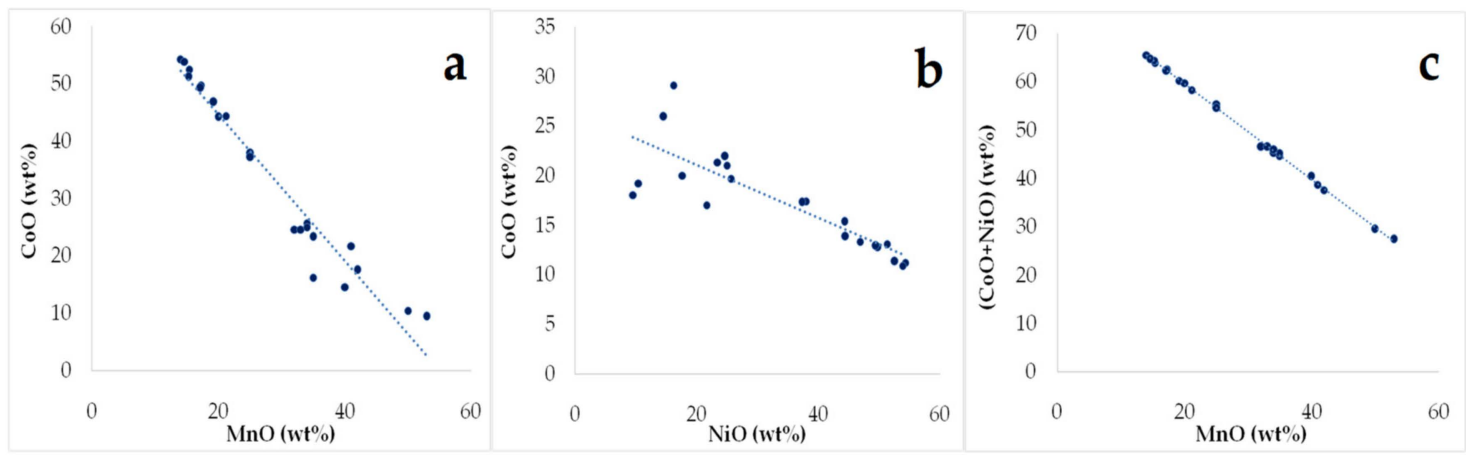

Figure 7. Plots $\mathrm{CoO}$ versus $\mathrm{MnO}, \mathrm{NiO},(\mathbf{a}, \mathbf{b})$ and $(\mathrm{CoO}+\mathrm{NiO})$ versus $\mathrm{MnO}(\mathbf{c})$. Data from Table 1. 
Table 1. Representative SEM-EDS analyses of (Co-Mn-Ni)-hydroxides from metamorphosed Fe-Ni laterites from E. Vermion.

\begin{tabular}{c|ccc|c|c|cccc}
\hline \multicolumn{10}{c}{ Content in wt \% } \\
\hline No. & MnO & $\mathrm{CoO}$ & $\mathrm{NiO}$ & Total & No. & MnO & CoO & NiO & Total \\
\hline V.1 & 25.0 & 38.0 & 17.4 & 80.4 & V.12 & 34.0 & 25.7 & 19.6 & 79.3 \\
V.2 & 40.0 & 14.5 & 26.0 & 80.5 & V.13 & 14.6 & 53.9 & 10.9 & 79.4 \\
V.3 & 14.0 & 54.3 & 11.2 & 79.5 & V.14 & 20.0 & 44.3 & 15.4 & 79.7 \\
V.4 & 15.4 & 52.5 & 11.4 & 79.3 & V.15 & 35.0 & 16.2 & 29.1 & 80.3 \\
V.5 & 15.3 & 51.3 & 13.1 & 79.7 & V.16 & 32.0 & 24.6 & 22.0 \\
V.6 & 17.3 & 49.7 & 12.8 & 79.8 & V.17 & 33.0 & 24.6 & 22.0 & 79.6 \\
V.7 & 17.1 & 49.4 & 12.9 & 79.4 & V.18 & 34.0 & 25.0 & 21.0 & 80.0 \\
V.8 & 19.2 & 46.9 & 13.3 & 79.4 & V.19 & 53.0 & 9.5 & 18.0 & 80.5 \\
V.9 & 21.2 & 44.4 & 13.9 & 79.5 & V.20 & 42.0 & 17.6 & 20.0 & 79.6 \\
V.10 & 25.0 & 37.3 & 17.3 & 79.6 & V.21 & 41.0 & 21.7 & 17.0 & 79.7 \\
V.11 & 35.0 & 23.4 & 21.3 & 79.7 & V.22 & 50.0 & 10.4 & 19.2 & 79.6 \\
\hline
\end{tabular}

\subsection{Chemical Composition of $\mathrm{Fe}-\mathrm{Ni} \pm \mathrm{Co}$ Laterite Ores}

Detailed studies on major Fe-Ni laterite deposits of Greece, in the frame of the European GeoNickel project, reported several typical bulk compositions for major and trace elements [36]. Representative analyses of various Fe-Ni laterite deposits and occurrences from Greece, as well as Albania, Serbia, and N. Macedonia (former F.Y.R.O.M.), completed for some critical element contents are shown in the Tables 2-5. Cobalt contents in laterite samples from Fe-Ni laterite deposits of Greece (Lokris, Kastoria, Palaiochori, W, Vermion, Olympos, Edessa, E. Vermion, and Skyros), Albania (Bitincka, Guri Pergjegjum, and Katjeli), Serbia (Topola), and N. Macedonia, former F.Y.R.O.M. (Rzanovo), range from 180 to $1600 \mathrm{mg} / \mathrm{kg}$, reaching values over $3100 \mathrm{mg} / \mathrm{kg}$ Co at the lowest contact of the Lokris bauxite laterite deposit with the carbonate basement (Table 2). In addition, it is clear that the REE, U, and Th are mostly associated with bauxite-laterites and to a lesser degree with $\mathrm{Fe}-\mathrm{Ni}$ laterites of karstic-type, whereas in Fe-Ni laterites with in situ features, such as the Kastoria and Bitincka, the $\Sigma$ REE content is $<10 \mathrm{mg} / \mathrm{kg}$, which appears to be consistent with their mineralogical composition (Figure 3e,f). In particular, the lowest part of the deposit lying on karstified Jurassic limestone is accompanied by an enrichment in $\Sigma$ REE, reaching values over $6000 \mathrm{mg} / \mathrm{kg} \Sigma \mathrm{REE}, 66 \mathrm{mg} / \mathrm{kg} \mathrm{U}, 25 \mathrm{mg} / \mathrm{kg}$ Th, and $1800 \mathrm{mg} / \mathrm{kg}$ As (Table 2). In general, the Co grades in the Balkan Peninsula range between 0.02 and $0.16 \%$ $\mathrm{wt} \% \mathrm{Co}$ and show a positive correlation with $\mathrm{Ni}$ and $\mathrm{Mn}$ (Figure 8). The majority of the Sc contents of lanthanides were 32-90 mg/kg in the Lokris deposits; $41-77 \mathrm{mg} / \mathrm{kg}$ Sc in the Kastoria, Palaiochori, and W. Vermion deposits; 30-82 mg/kg Sc in the Olympos, Edessa, E. Vermion, and Skyros Fe-Ni laterite occurrences; and 12-96 mg/kg Sc in the Albania, Serbia, and N. Macedonia, former F.Y.R.O.M., deposits (Tables 2-4). Increasing Fe contents are accompanied by elevated Sc, the best positive correlation between $\mathrm{Sc}$ and Fe being evidenced in the Lokris deposit and W. Vermion (Tables 2-5 and Figure 9). 
Table 2. Major and trace element contents in representative $\mathrm{Fe}-\mathrm{Ni} \pm \mathrm{Co}$ laterite and bauxite laterite samples from the Lokris and Evia deposits.

\begin{tabular}{|c|c|c|c|c|c|c|c|c|c|c|c|c|c|c|c|c|c|c|c|c|c|}
\hline \multicolumn{11}{|c|}{ LOKRIS } & \multicolumn{4}{|c|}{ LOKRIS } & \multicolumn{5}{|c|}{ LOKRIS } & \multicolumn{2}{|c|}{ EVIA } \\
\hline \multicolumn{11}{|c|}{ Profile from top to underlying base of carbonates } & \multicolumn{4}{|c|}{ Bauxitic laterite } & \multicolumn{5}{|c|}{ Fe-Ni laterite } & \multicolumn{2}{|c|}{ Fe-Ni laterite } \\
\hline $\mathrm{wt} \%$ & $\mathrm{~N}-3 \mathrm{H}$ & $\mathrm{N}-3 \mathrm{D}$ & $\mathrm{N}-3 \mathrm{C}$ & $\mathrm{N}-3 \mathrm{Ba}$ & $\mathrm{N}-3 \mathrm{Bb}$ & $\mathrm{N}-2 \mathrm{~B}$ & $\mathrm{~N}-1 \mathrm{Ba}$ & $\mathrm{N}-1 \mathrm{Bb}$ & LAR4 & $\mathrm{N}-18$ & $\mathrm{~N}-20$ & $\mathrm{~N}-22$ & $\mathrm{~N}-32$ & $\mathrm{~N}-36$ & $\mathrm{~N}-11$ & $\mathrm{~N}-14$ & $\mathrm{~N}-15$ & N16 & $\mathrm{N}-17$ & Ev.1 & Ev.2 \\
\hline $\mathrm{SiO}_{2}$ & 1.85 & 24.2 & 23.1 & 11.5 & 19.6 & 15.9 & 19.5 & 20.2 & 11.6 & 5.1 & 7.4 & 5.8 & 5.6 & 20.9 & 34.0 & 24.1 & 23.8 & 31.2 & 19.5 & 26.8 & 15.9 \\
\hline $\mathrm{Al}_{2} \mathrm{O}_{3}$ & 44.1 & 20.3 & 18.8 & 43.8 & 22.4 & 16.1 & 23.6 & 24,1 & 36.4 & 33.6 & 40.5 & 29.9 & 31.2 & 25.2 & 8.6 & 6.7 & 16.9 & 7.1 & 6.25 & 5.8 & 7.1 \\
\hline $\mathrm{TiO}_{2}$ & 2.7 & 1.1 & 1.25 & 0.03 & 0.55 & 0.35 & 0.4 & 0.38 & 1.9 & 2.25 & 2.6 & 1.95 & 1.95 & 1.25 & 0.4 & 0.3 & 1.2 & 0.37 & 0.3 & 0.13 & 0.12 \\
\hline $\mathrm{CaO}$ & 0.15 & 0.2 & 0.41 & 3.3 & 1.6 & 0.95 & 0.55 & 0.6 & 2.8 & 0.6 & 0.15 & 0.1 & 0.2 & 0.3 & 0.35 & 0.5 & 3.1 & 2.2 & 0.3 & 1.4 & 0.5 \\
\hline $\mathrm{MgO}$ & 0.25 & 3.6 & 3.4 & 0.25 & 2.14 & 1.25 & 1.2 & 1.6 & 2.4 & 0.7 & 0.85 & 0.95 & 1.2 & 3.7 & 3.4 & 2.8 & 3.8 & 4.4 & 2.3 & 0.03 & 0.1 \\
\hline $\begin{array}{c}\mathrm{MnO} \\
\mathrm{mg} / \mathrm{kg}\end{array}$ & 0.17 & 0.3 & 0.1 & 0.8 & 0.4 & 0.55 & 0.75 & 0.69 & 0.2 & 0.17 & 0.12 & 0.15 & 0.25 & 0.22 & 0.4 & 0.2 & 0.18 & 0.3 & 0.32 & 0.12 & 0.4 \\
\hline $\mathrm{Cr}$ & 4900 & 11,000 & 13,000 & 340 & 5700 & 3500 & 3800 & 3900 & 9100 & 7000 & 8700 & 8300 & 5300 & 4400 & 19,000 & 16,000 & 10,000 & 23,000 & 17,000 & 20,000 & 22,000 \\
\hline Co & 57 & 2200 & 430 & 3100 & 1400 & 1400 & 2200 & 2200 & 580 & 280 & 230 & 300 & 560 & 1400 & 510 & 470 & 750 & 520 & 410 & 590 & 830 \\
\hline As & 230 & 140 & 200 & 12 & 790 & 1800 & 680 & 130 & 140 & 240 & 130 & 250 & 300 & 2600 & 2.0 & 2.0 & 6.0 & 12 & 5.0 & 2.0 & 2.0 \\
\hline Sc & 90 & 58 & 49 & 13 & 34 & 32 & 45 & 44 & 45 & 74 & 69 & 79 & 76 & 68 & 46 & 56 & 47 & 41 & 55 & 60 & 67 \\
\hline $\mathrm{La}$ & 56 & 144 & 172 & 2510 & 1570 & 2740 & 2420 & 2370 & 73 & 115 & 72 & 79 & 176 & 129 & 15 & 9.0 & 39 & 8.0 & 19 & 4.0 & 5.0 \\
\hline $\mathrm{Ce}$ & 207 & 126 & 84 & 401 & 242 & 292 & 351 & 348 & 107 & 164 & 132 & 128 & 313 & 1030 & 50 & 25 & 72 & 44 & 67 & 57 & 40 \\
\hline $\mathrm{Nd}$ & $<10$ & 110 & 160 & 2040 & 1460 & 2740 & 2250 & 2690 & 50 & 70 & 60 & 50 & 80 & 140 & 10 & $<10$ & 30 & $<10$ & 10 & $<10$ & $<10$ \\
\hline Sm & 3.6 & 24 & 34 & 401 & 233 & 404 & 391 & 385 & 9.9 & 12 & 11 & 9.7 & 11 & 30 & 2.7 & 1.2 & 5.6 & 1 & 1.8 & 0.9 & 0.8 \\
\hline $\mathrm{Eu}$ & 1.2 & 6.5 & 9.2 & 89 & 54 & 91 & 97 & 95 & 2.4 & 3.6 & 3.9 & 4.1 & 2.8 & 8.7 & 0.7 & 0.3 & 1.2 & 0.5 & 0.5 & 0.4 & 0.3 \\
\hline $\mathrm{Tb}$ & 1.0 & 4.0 & 4.9 & 33 & 30 & 38 & 35 & 32 & 0.9 & $\begin{array}{l}1.8 \\
\end{array}$ & 1.8 & 1.0 & 2.1 & 4.5 & $<0.5$ & $<0.5$ & $<0.5$ & 0.6 & $<0.5$ & $<0.5$ & $<0.5$ \\
\hline Th & 25 & 12 & $<10$ & $<10$ & $<10$ & $<10$ & $<10$ & $<10$ & 9.5 & 28 & 31 & 21 & 15 & 10 & 2.2 & 1.1 & 7.0 & 1.0 & 2.2 & 1.7 & 1.2 \\
\hline $\mathrm{U}$ & 6.9 & 13 & 18 & 66 & 41 & 46 & 58 & 58.4 & 5.6 & 15 & 14 & 17 & 12 & 7 & $<0.5$ & $<0.5$ & 4.2 & $<0.5$ & 2.3 & $<0.5$ & $<0.5$ \\
\hline$\Sigma$ REE & 273 & 438 & 480 & 5506 & 3617 & 6337 & 5581 & 5958 & 265 & 377 & 291 & 279 & 596 & 1366 & 81 & 37 & 152 & 55 & 100 & 63 & 47 \\
\hline$\mu \mathrm{g} / \mathrm{kg}$ & & & & & & & & & & & & & & & & & & & & & \\
\hline $\mathrm{Pt}$ & $<10$ & 22 & 23 & $<10$ & $<10$ & $<10$ & $<10$ & $<10$ & $<10$ & $<10$ & $<10$ & $<10$ & $<10$ & 12 & 17 & 20 & 15 & 86 & $<10$ & 19 & 13 \\
\hline $\mathrm{Pd}$ & 1 & 19 & 9 & 5 & 5 & 5 & 3 & 3 & $<1$ & $<1$ & $<1$ & $<1$ & $<1$ & 1 & 3 & 4 & 2 & 6 & 1 & 17 & 1 \\
\hline $\mathrm{Au}$ & 18 & 14 & 36 & $<5$ & $<5$ & $<5$ & $<5$ & $<5$ & $<5$ & $<5$ & $<5$ & $<5$ & 25 & $<5$ & $<5$ & $<5$ & $<5$ & $<5$ & $<5$ & $<5$ & 5 \\
\hline
\end{tabular}


Table 3. Major and trace element contents in representative $\mathrm{Fe}-\mathrm{Ni} \pm \mathrm{Co}$ laterite and bauxite laterite samples from deposits of northern Greece.

\begin{tabular}{|c|c|c|c|c|c|c|c|c|c|c|c|c|c|c|c|c|c|c|c|c|c|}
\hline \multicolumn{7}{|c|}{ KASTORIA } & \multirow{2}{*}{\multicolumn{2}{|c|}{$\begin{array}{l}\text { PALAIOCHORI } \\
\text { Fe-Ni laterite }\end{array}$}} & \multicolumn{13}{|c|}{ W. VERMION } \\
\hline \multicolumn{3}{|c|}{ Goethite zone } & \multicolumn{4}{|c|}{ Pisolitic zone } & & & \multicolumn{2}{|c|}{ Saprolite } & \multicolumn{4}{|c|}{$\mathrm{Fe}-\mathrm{Ni}$ laterite } & \multicolumn{3}{|c|}{ Saprolite } & \multicolumn{3}{|c|}{ Bauxitic laterite } & \multirow[b]{2}{*}{ PW5 } \\
\hline $\mathrm{wt} \%$ & Ka-4a & Ka-4b & Ka-5 & Ka-6 & Ka-7 & Ka-8 & P.G.2 & $\begin{array}{l}\text { P.G.3 } \\
\end{array}$ & PR1 & PR2 & PR5 & PR6 & WV4 & WV5 & WV6 & U.R. & PV1 & $\begin{array}{l}\text { PV2 } \\
\end{array}$ & PV3 & PW4 & \\
\hline $\mathrm{SiO}_{2}$ & 36.6 & 22.0 & 3.8 & 3.8 & 4.5 & 4.05 & 12.1 & 17.8 & 45 & 30 & 9.0 & 16.5 & 38 & 39 & 15.2 & 37 & 17.5 & 14.5 & 13 & 14 & 13 \\
\hline $\mathrm{Al}_{2} \mathrm{O}_{3}$ & 1.2 & 2.2 & 3 & 5.1 & 1.8 & 3.4 & 4.7 & 5.4 & 0.5 & 0.2 & 3.34 & 13 & 3.6 & 1.8 & 12.5 & 1.0 & 29 & 32 & 31.9 & 32 & 37.4 \\
\hline $\mathrm{CaO}$ & 5.25 & 0.56 & 0.2 & 0.3 & 0.6 & 0.1 & 3.6 & 5.4 & 0.3 & 18 & 0.5 & 0.4 & 0.3 & 0.7 & 0.38 & 0.5 & 0.8 & 0.8 & 0.6 & 0.9 & 0.9 \\
\hline $\mathrm{TiO}_{2}$ & 0.01 & 0.02 & 0.03 & 0.03 & 0.03 & 0.1 & 0.18 & 0.21 & 0.1 & 0.1 & 0.2 & 0.4 & 0.1 & 0.1 & 0.11 & 0.1 & 1.28 & 1.7 & 1.65 & 1.69 & 1.15 \\
\hline $\mathrm{MgO}$ & 1.1 & 3.25 & 0.6 & 0.55 & 0.8 & 0.6 & 2.86 & 5.11 & 25.9 & 23.2 & 1.7 & 1.9 & 7.4 & 20 & 4.65 & 37 & 3.6 & 2.4 & 2.1 & 2.7 & 2.1 \\
\hline $\mathrm{MnO}$ & 0.95 & 0.88 & 0.25 & 1.7 & 0.79 & 0.3 & 0.25 & 0.42 & 0.24 & 0.11 & 0.97 & 0.61 & 0.41 & 0.33 & 0.62 & 0.1 & 0.37 & 0.41 & 0.24 & 0.36 & 0.26 \\
\hline $\begin{array}{l}\mathrm{P}_{2} \mathrm{O}_{5} \\
\mathrm{mg} / \mathrm{kg}\end{array}$ & - & - & - & - & - & - & - & - & 0.01 & 0.01 & 0.01 & 0.1 & 0.05 & 0.01 & 0.01 & 0.06 & 0.48 & 0.31 & 0.27 & 0.32 & 0.2 \\
\hline $\mathrm{Ni}$ & 8500 & 10,500 & 8000 & 9100 & 6800 & 4400 & 9000 & 17,800 & 5500 & 2200 & 15,000 & 6900 & 10,200 & 9500 & 7800 & 3100 & 5200 & 5200 & 6400 & 6400 & 4200 \\
\hline $\mathrm{Cr}$ & 16,000 & 23,000 & 20,000 & 15,000 & 23,000 & 17,000 & 13,000 & 10,500 & 5800 & 2500 & 22,000 & 12,900 & 11,500 & 11,400 & 11,000 & 3800 & 5500 & 4400 & 3800 & 4100 & 3600 \\
\hline Co & 1100 & 1200 & 330 & 820 & 420 & 330 & 800 & 790 & 300 & 200 & 1300 & 700 & 500 & 400 & $82 \mathrm{O}$ & 340 & 400 & 320 & 400 & 400 & 400 \\
\hline Sc & 23 & 41 & 66 & 65 & 55 & 42 & 77 & 75 & 2.0 & 5.0 & 68 & 60 & 50 & 56 & 58 & 6 & 29 & 64 & 68 & 65 & 70 \\
\hline As & $<2$ & $<2$ & 3 & 15 & 14 & 13 & 4 & 3 & $<2$ & $<2$ & 7 & 6 & 10 & 8 & 6 & $<2$ & 7 & 11 & 12 & 8 & 10 \\
\hline $\mathrm{La}$ & $<1$ & $<1$ & $<1$ & $<1$ & 3.0 & $<1$ & 19 & 10 & 2.0 & 3.0 & 18 & 29 & 19 & 15 & 170 & 2.0 & 103 & 115 & 114 & 117 & 212 \\
\hline $\mathrm{Ce}$ & $<3$ & $<3$ & $<3$ & $<3$ & $<3$ & $<3$ & 32 & 3 & 3 & 4 & 31 & 62 & 38 & 20 & 15 & 4 & 140 & 145 & 145 & 150 & 230 \\
\hline $\mathrm{Nd}$ & $<10$ & $<10$ & $<10$ & $<10$ & $<10$ & $<10$ & $<10$ & $<10$ & $<10$ & $<10$ & 10 & 20 & 10 & 10 & 38 & $<10$ & 33 & 35 & 36 & 33 & 75 \\
\hline Sm & $<0.5$ & $<0.5$ & $<0.5$ & $<0.5$ & $<10$ & $<0.5$ & 1.9 & $<0.5$ & $<0.5$ & 11 & 3.8 & 0.4 & 2.9 & 0.9 & 20 & $<0.5$ & 12 & 14 & 17 & 18 & 29 \\
\hline $\mathrm{Eu}$ & 0.4 & 0.5 & 0.3 & 0.3 & 0.3 & $<0.2$ & 0.8 & $<0.2$ & $<0.2$ & 0.3 & 0.2 & 2.1 & 0.8 & 1.6 & 6.5 & $<0.2$ & 1.8 & 2.2 & 2.8 & 3.4 & 4.7 \\
\hline $\mathrm{Lu}$ & $<0.05$ & $<0.05$ & $<0.05$ & $<0.05$ & $<0.05$ & $<0.05$ & 0.15 & $<0.05$ & $<0.05$ & 0.1 & 0.45 & 0.65 & 0.37 & 0.45 & 5.5 & $<0.05$ & 1.1 & 1.3 & 1.5 & 1.6 & 2.5 \\
\hline Th & $<1$ & $<1$ & $<1$ & $<1$ & $<1$ & $<1$ & 6.3 & $<1$ & 0.7 & 0.8 & 3.1 & 5.6 & 3.1 & 1.9 & 1.4 & $<0.5$ & 19 & 20 & 17 & 18 & 28 \\
\hline $\begin{array}{c}\mathrm{U} \\
\mu \mathrm{g} / \mathrm{kg}\end{array}$ & $<1$ & $<1$ & $<1$ & $<1$ & 1.3 & $<1$ & $<1$ & $<1$ & 0.9 & 0.9 & 3.6 & 4.8 & 1.6 & 1.6 & 3.2 & $<0.5$ & 4.2 & 4.0 & 3.9 & 4.2 & 5.0 \\
\hline $\mathrm{Pt}$ & 12 & 12 & 15 & 88 & 40 & 10 & 25 & 25 & 11 & $<10$ & 82 & 56 & 34 & 28 & 39 & $<10$ & 25 & 26 & 54 & 48 & 29 \\
\hline $\mathrm{Pd}$ & 3 & 6 & $<1$ & $<1$ & $<1$ & $<1$ & $<1$ & 6 & 5 & $<1$ & 45 & 38 & 8 & 8 & 186 & $<1$ & 5 & 4 & 10 & 7 & 5 \\
\hline $\mathrm{Au}$ & $<5$ & $<5$ & $<5$ & $<5$ & 9 & $<5$ & $<5$ & $<5$ & $<5$ & $<5$ & 5 & 5 & 4 & 5 & 17 & $<5$ & 5 & 5 & 15 & 16 & 7 \\
\hline
\end{tabular}


Table 4. Major and trace element contents from metamorphosed laterite occurrences of northern Greece.

\begin{tabular}{|c|c|c|c|c|c|c|c|c|c|c|c|}
\hline \multicolumn{4}{|c|}{ OLYMPOS } & \multicolumn{3}{|c|}{ E. VERMION } & \multicolumn{3}{|c|}{ EDESSA } & \multicolumn{2}{|c|}{ SKYROS } \\
\hline$w t \%$ & OL.1 & $\mathrm{O} .3$ & OL.5x & A.K.10 & AL2 & ST.B & Ed.P10 & Ed.P.11 & Ed.P.3 & Sk.3 & Sk.4 \\
\hline $\mathrm{SiO}_{2}$ & 4.2 & 3.9 & 7.0 & 22.3 & 10.1 & 15.1 & 17.5 & 22.7 & 14.2 & 11 & 11.1 \\
\hline $\mathrm{Al}_{2} \mathrm{O}_{3}$ & 3.4 & 2.85 & 5.8 & 5.5 & 11.1 & 7.5 & 8.65 & 9.5 & 1.4 & 7.4 & 9.4 \\
\hline $\mathrm{Fe}_{2} \mathrm{O}_{3}$ & 58.34 & 59.7 & 65.64 & 44.4 & 67.8 & 54.8 & 59.5 & 52.2 & 67.65 & 63.52 & 59.63 \\
\hline $\mathrm{TiO}_{2}$ & 0.07 & 0.09 & 0.06 & 1.28 & 1.8 & 0.15 & 0.27 & 0.31 & 0.2 & 0.21 & 0.27 \\
\hline $\mathrm{CaO}$ & 0.07 & 0.05 & 0.05 & 7.0 & 0.05 & 1.9 & 0.46 & 2.4 & 0.1 & $<1$ & $<1$ \\
\hline $\mathrm{MgO}$ & 3.4 & 2.87 & 4.35 & 3.6 & 1.05 & 11.5 & 3.25 & 3.5 & 7.05 & 2.4 & 2.05 \\
\hline $\mathrm{MnO}$ & 1.05 & 0.77 & 0.27 & 0.37 & 0.05 & 0.49 & 0.58 & 0.38 & 1.1 & 0.36 & 0.16 \\
\hline $\begin{array}{c}\mathrm{P}_{2} \mathrm{O}_{5} \\
\mathrm{mg} / \mathrm{kg}\end{array}$ & 0.21 & 0.15 & 0.17 & 0.31 & 0.26 & 0.28 & 0.45 & 0.38 & 0.41 & - & - \\
\hline $\mathrm{Ni}$ & 8600 & 9300 & 16,000 & 5200 & 1600 & 8900 & 9500 & 6300 & 11,000 & 9800 & 10,000 \\
\hline $\mathrm{Cr}$ & 91,000 & 82,000 & 20,000 & 10,000 & 25,000 & 17,000 & 9600 & 7400 & 39,000 & 22,000 & 23,000 \\
\hline Co & 300 & 320 & 1200 & 400 & 180 & 1100 & 800 & 430 & 1200 & 360 & 320 \\
\hline $\mathrm{Zn}$ & 340 & 430 & 850 & 500 & 89 & 500 & 60 & 70 & 290 & 60 & 110 \\
\hline Sc & 31 & 30 & 28 & 57 & 67 & 59 & 82 & 80 & 30 & 64 & 61 \\
\hline As & 7.0 & 8.0 & 19 & 57 & 16 & 22 & 4.0 & 2.0 & 17 & 2.0 & 24 \\
\hline $\mathrm{La}$ & 1.0 & 1.0 & 10 & 11 & 44 & 18 & 75 & 40 & 13 & 6.0 & 8.0 \\
\hline $\mathrm{Ce}$ & 3.0 & 3.0 & 19 & 32 & 95 & 28 & 70 & 76 & 40 & 14 & 23 \\
\hline $\mathrm{Nd}$ & $<10$ & $<10$ & $<10$ & 10 & 40 & 10 & 49 & 30 & 10 & $<10$ & $<10$ \\
\hline $\mathrm{Eu}$ & 0.6 & 0.9 & 0.6 & 0.5 & 3.0 & 0.8 & 0.3 & 1.5 & 0.5 & $<0.2$ & 0.6 \\
\hline $\mathrm{Tb}$ & $<0.5$ & $<0.5$ & $<0.5$ & 0.6 & 1.1 & 3.5 & 0.5 & 0.6 & 0.6 & $<0.5$ & $<0.5$ \\
\hline Yp & 1 & 0.5 & 0.9 & 1.3 & 3.7 & 9.0 & 1.8 & 1.6 & 0.6 & 0.9 & 1.1 \\
\hline $\mathrm{Lu}$ & 0.19 & 0.05 & 0.05 & 0.18 & 0.6 & 1.22 & 0.22 & 0.23 & 0.05 & 0.16 & 0.15 \\
\hline Th & 0.6 & $<0.5$ & 1.0 & 19 & 20 & $<0.5$ & 4.0 & 3.7 & 2.6 & 3.6 & 2.8 \\
\hline $\mathrm{U}$ & 0.5 & 2.3 & 0.6 & 4.2 & 3.9 & 2.8 & 2.1 & 2.6 & 1.8 & 1.0 & 1.0 \\
\hline \multicolumn{12}{|l|}{$\mu \mathrm{g} / \mathrm{kg}$} \\
\hline $\mathrm{Pt}$ & $<10$ & 59 & 38 & 58 & 33 & 10 & 10 & 10 & 48 & $<10$ & 48 \\
\hline $\mathrm{Pd}$ & 1.0 & 2.0 & 2.0 & 9.0 & 1.0 & 6.0 & 26 & 23 & 22 & 25 & 22 \\
\hline $\mathrm{Au}$ & 2.0 & 8.0 & 19 & 11 & 13 & 20 & 3.0 & 3.0 & 15 & 5.0 & 15 \\
\hline
\end{tabular}


Table 5. Major and trace element contents in representative Fe-Ni \pm Co laterite deposits from Albania, Serbia, and N. Macedonia (former F.Y.R.O.M.).

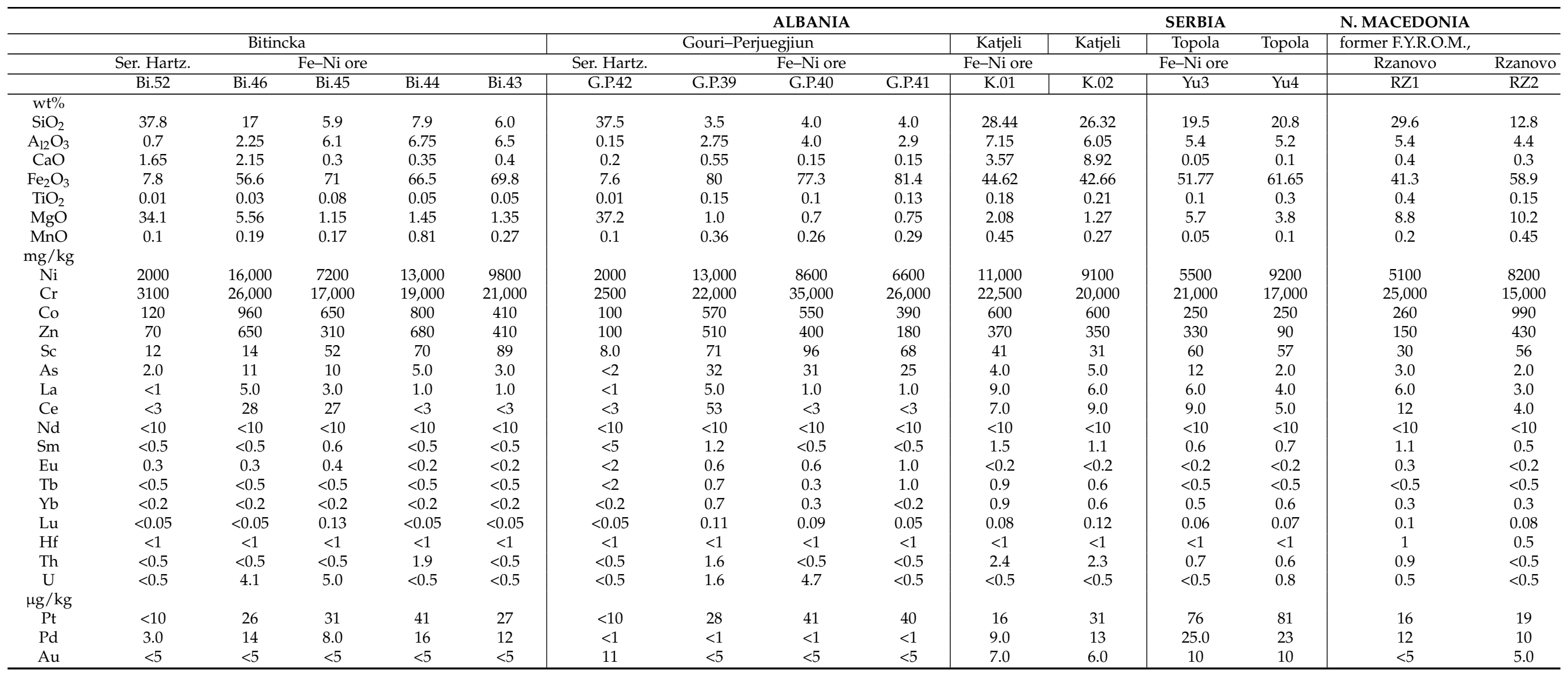




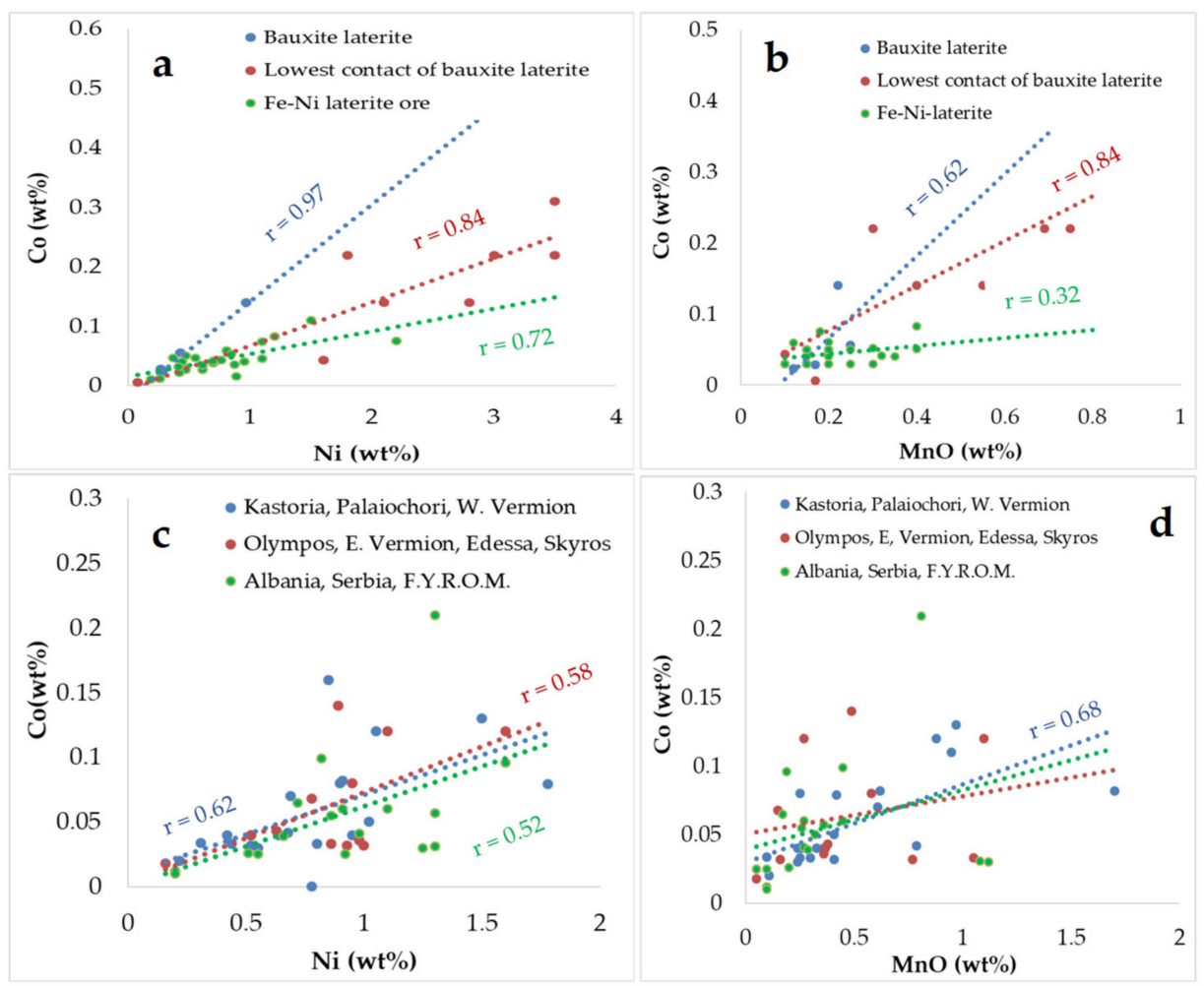

Figure 8. Plots of Co versus $\mathrm{Ni}$ and $\mathrm{MnO}$ from the Lokris (a,b), and other Fe-Ni laterite deposits from Greece, Albania, Serbia, and N. Macedonia, former F.Y.R.O.M. (c,d), revealed the pronounced positive correlation between $\mathrm{Co}$ and $\mathrm{Ni}, \mathrm{Mn}$ at the lowest parts of the Lokris deposit, near the contact with the carbonate basement. Data from Tables 2-5.

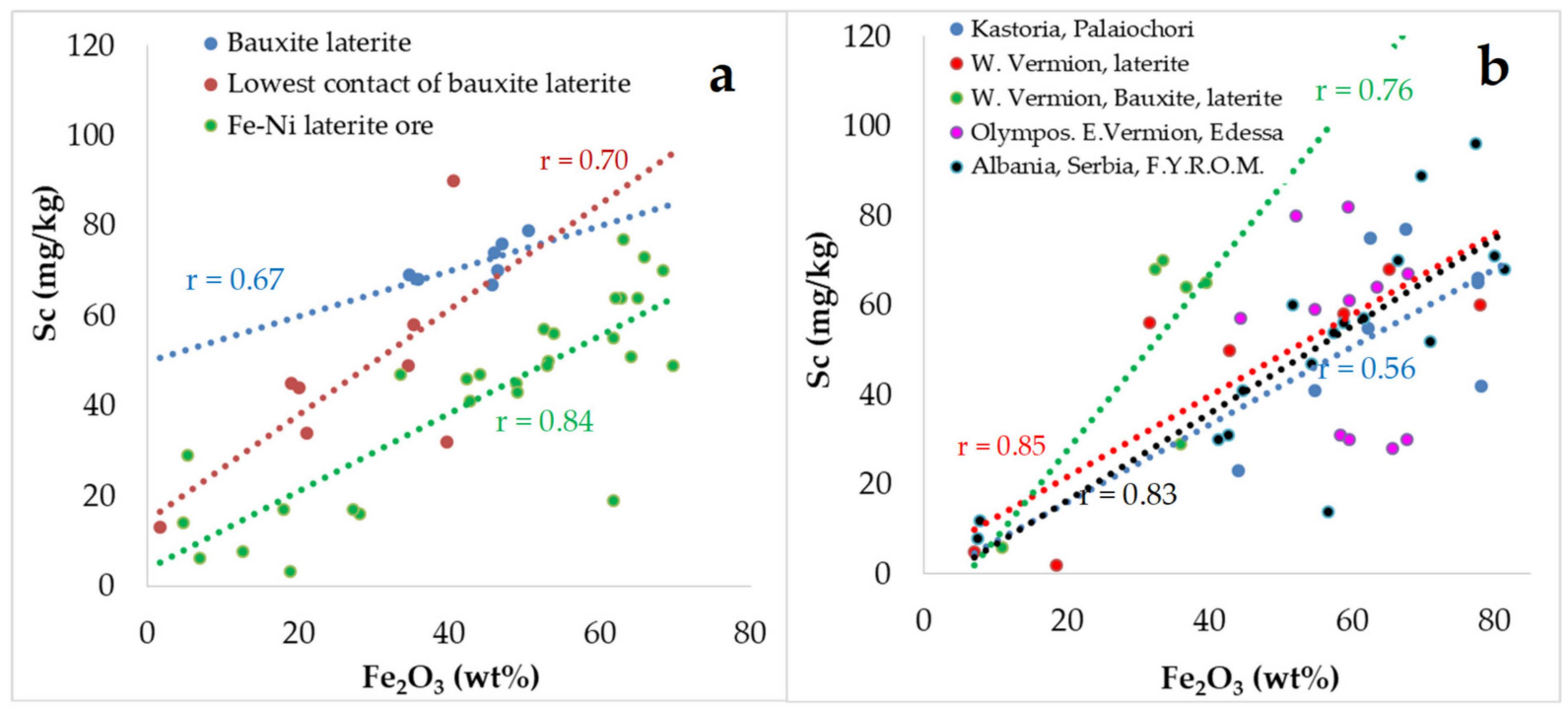

Figure 9. Plots of $\mathrm{Sc}$ versus $\mathrm{Fe}_{2} \mathrm{O}_{3}$ for Fe-Ni laterites and bauxite laterites from the Balkan Peninsula. The best positive correlation between Sc and Fe is observed in the Fe-Ni laterite deposits of Lokris (a) and W. Vermion (b). Data from Tables 2-5.

Assuming that values $>1$ and $<1$ are called positive and negative anomalies, respectively, chondrite normalized REE patterns show in general negative slopes from La-Eu and slight positive slopes from $\mathrm{Tb}-\mathrm{Lu}$ for the $\mathrm{Fe}-\mathrm{Ni}$ laterites and bauxite laterite samples from the Lokris and Evia (Figure 10a) and W. Vermion (Figure 10b), except the samples from the 
lowest part of the Lokris deposit, showing a negative Ce anomaly (Figure 10a). In addition, a positive $\mathrm{Nd}$ anomaly in the later samples is observed that seems to be consistent with the occurrence of (hydroxyl)bastnaesite-(Nd) and ( $\mathrm{La}, \mathrm{Nd}, \mathrm{Y}$ )-bastnaesite (Figure 3e,f) $[26,29,30]$. Laterites from $\mathrm{W}$. Vermion are characterized by positive Ce and Eu anomalies. In general, negative slopes are a common feature of the chondrite normalized REE patterns of laterites from northern Greece (Figure 10c), Albania, Serbia, and N. Macedonia, former F.Y.R.O.M. (Figure 10d), with varying positive and negative anomalies.
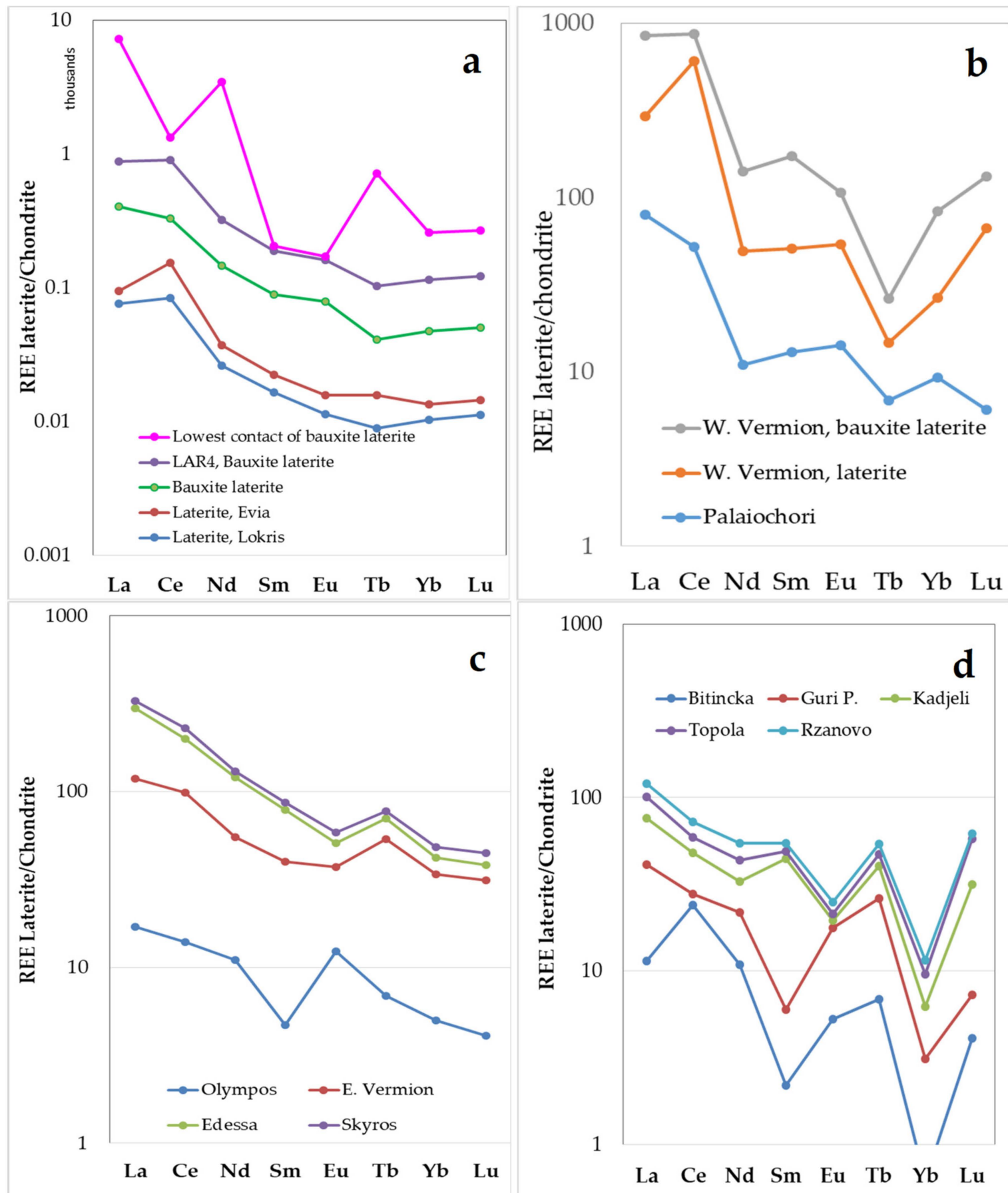

La Ce Nd Sm Eu Tb Yb Lu

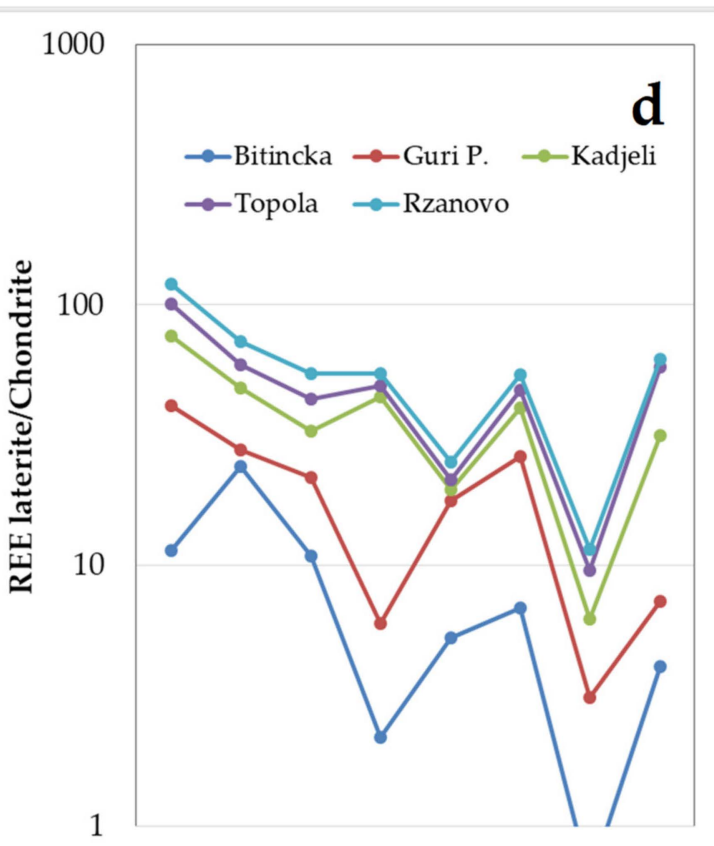

La Ce $\mathrm{Nd} \mathrm{Sm}$ Eu $\mathrm{Tb} \quad \mathrm{Yb} \quad \mathrm{Lu}$

Figure 10. Chondrite normalized REE-patterns for average values of samples from Fe-Ni laterites and bauxite laterites, from the Lokris and Evia (a), Palaiochori and W. Vermion (b), Olympos, E. Vermion, Edessa, and Skyros (c) and Albania, Serbia and N. Macedonia (former F.Y.R.O.M.) (d). Data from Tables 2-5. 
In general, the PGE content, reaching up to $88 \mu \mathrm{g} / \mathrm{kg}$ Pt and $45 \mu \mathrm{g} / \mathrm{kg}$ Pd (up to $186 \mu \mathrm{g} / \mathrm{kg}$ Pd in one sample), is higher in $\mathrm{Fe}-\mathrm{Ni} \pm$ Co laterites than in bauxite laterites (Tables 2-5 and Figure 11d-f) and bauxites [37]. A common feature of the studied deposits from the Balkan Peninsula, including two Fe-Ni laterite profiles from the Gouri-Perjuegjiun and Bitincka deposits of Albania, the Kastoria, and W. Vermion laterites, is the higher $\mathrm{Pt}$ than Pd contents in ores compared to parent peridotites, their concentration mostly occuring in the pelitomorphic and pisolitic-oolitic types (Tables 2-5) [16,18].
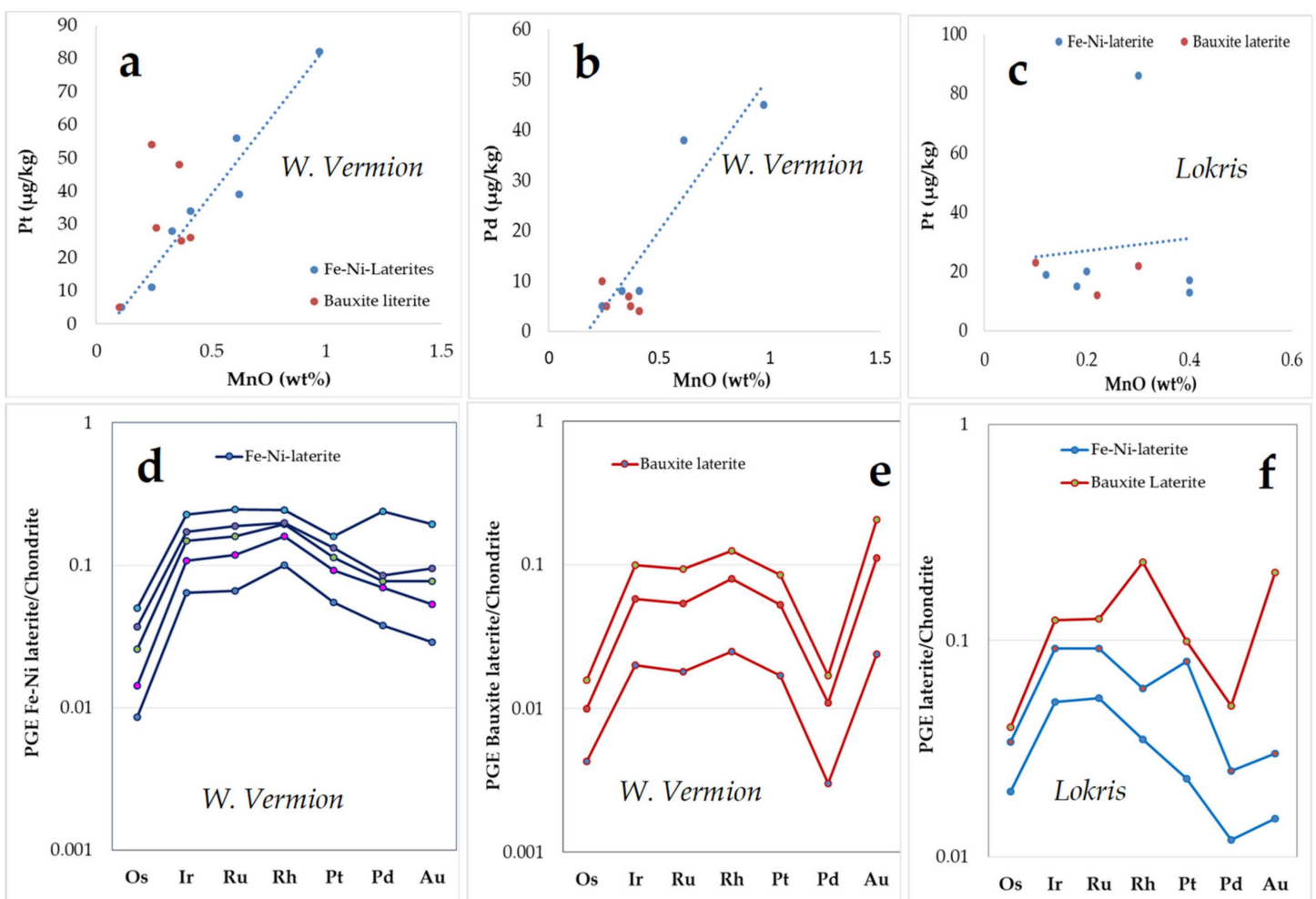

Figure 11. Plots of Pt and Pd versus $\mathrm{MnO}(\mathbf{a}-\mathbf{c})$ and chondrite normalized PGE patterns for Fe-Ni laterites and bauxite from W. Vermion and Lokris (d-f). Data from Tables 2-5.

Any relationship between Sc and Pt or Pd is not clear, but there is a positive trend in the laterite samples from W. Vermion (Figure 12a,b), whereas both Pt and Pd exhibit a negative trend with the $\Sigma R E E$ (Figure $12 \mathrm{~b}$ ). In contrast, there is a positive trend between the $\Sigma$ REE and Th, U, and $\mathrm{P}_{2} \mathrm{O}_{5}$ contents (Figure $12 \mathrm{c}-\mathrm{e}$ ), as well as between $\mathrm{Sc}_{-}-\mathrm{P}_{2} \mathrm{O}_{5}$ contents (Figure 12f). 

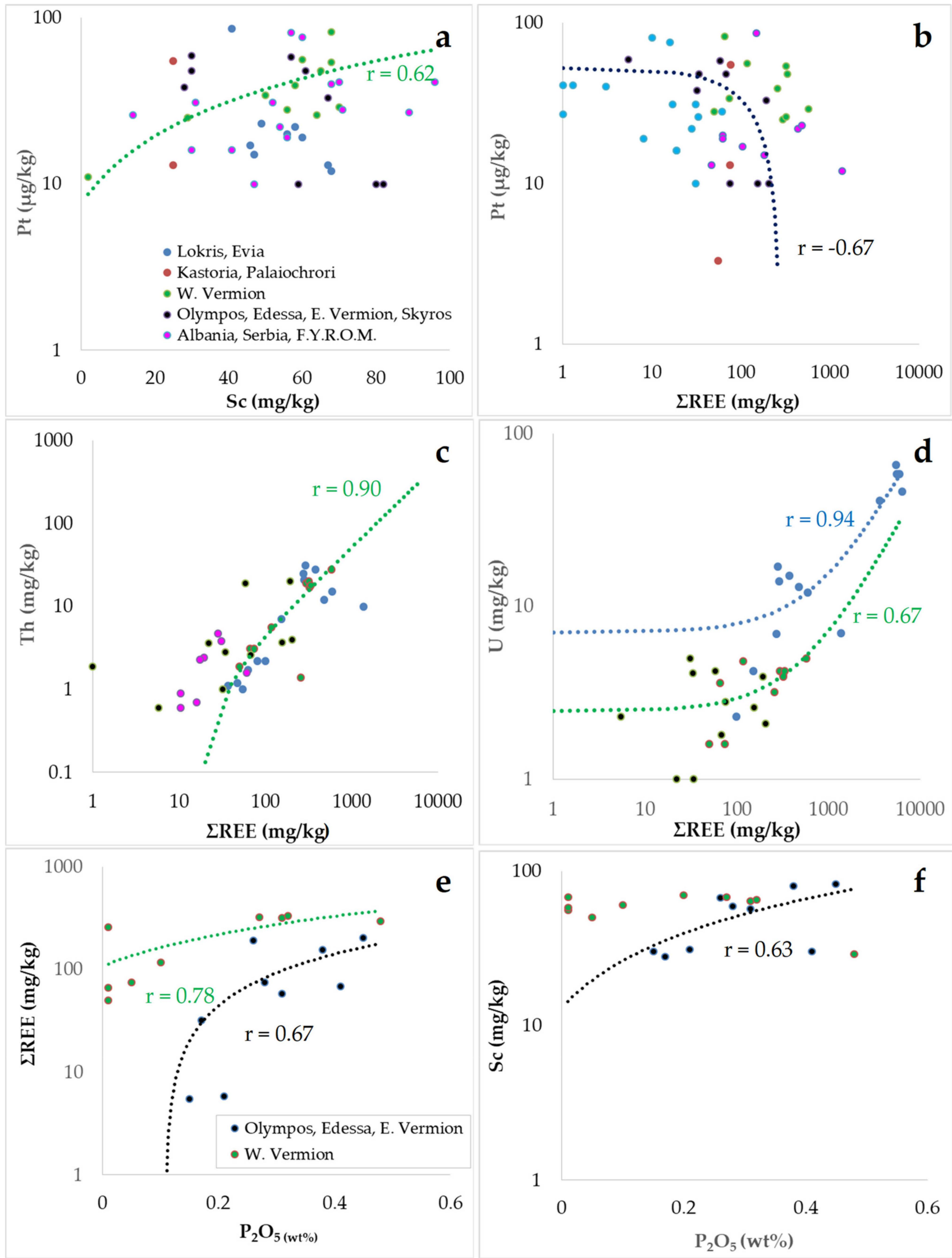

Figure 12. Plots of Pt versus $\mathrm{Sc}$ and $\Sigma \operatorname{REE}(\mathbf{a}, \mathbf{b})$; Th and U versus $\Sigma$ REE $(\mathbf{c}, \mathbf{d})$, and $\Sigma$ REE, Sc versus $\mathrm{P}_{2} \mathrm{O}_{5}(\mathbf{e}, \mathbf{f})$. Data from Tables 2-5. 


\subsection{Environmental Impact from Mining and Smelting of Fe-Ni Laterites}

Integrated approaches to the soil-groundwater-plant/crops compositional variations related to the weathering of rocks/ores, mining, and smelting of laterites and the preliminary results of leaching experiments of $\mathrm{Fe}-\mathrm{Ni}$ laterite have been presented in previous publications and will be discussed. Furthermore, BSE images from the unpolished parts of the Nissi (Lokris) bauxite laterite ore are given in the present study (Figure 4) in order to discuss the role of organic matter into heavy metal biomobilization and biomineralization in soil and the contamination of groundwater affected by rock/ore weathering and mining of laterite deposits.

\subsubsection{Metallurgical Residues (Slag)}

The result of the reductive smelting of the laterite is the formation of two separate phases, the metallic Fe-Ni and the slag residue. Bulk chemical analyses of representative samples of pyro-metallurgical residue (slag96 and slag14 samples) from the Larymna plant, indicated a significant $\mathrm{Cr}$ content (Table 6).

Table 6. Chemical composition of slag (smelting residue) from Fe-Ni-Co laterites, Larymna plant, Lokris.

\begin{tabular}{|c|c|c|c|c|c|c|c|}
\hline & & & Detection & & & & Detection \\
\hline $\mathrm{mg} / \mathrm{kg}$ & Slag96 & Slag14 & limit & $\mathrm{mg} / \mathrm{kg}$ & Slag96 & Slag14 & limit \\
\hline $\mathrm{Cu}$ & 16 & 15 & 0.5 & $\mathrm{Yb}$ & 1.0 & 1.1 & 0.5 \\
\hline $\mathrm{Pb}$ & 5.0 & 6.2 & 0.5 & $\mathrm{Lu}$ & 0.5 & 0.5 & 0.5 \\
\hline $\mathrm{Zn}$ & 180 & 92 & 5 & $\mathrm{Nb}$ & 4.3 & 4.1 & 0.5 \\
\hline $\mathrm{Ni}$ & 2400 & 930 & 0.5 & $Y$ & 16 & 15 & 0.5 \\
\hline $\mathrm{Co}$ & 210 & 110 & 1 & Hf & 1.3 & 1.4 & 0.5 \\
\hline Mn & 2700 & 2820 & 5 & $\mu \mathrm{g} / \mathrm{kg}$ & & & \\
\hline $\mathrm{Cr}$ & 19,000 & 20,600 & 1 & $\mathrm{Pt}$ & $<10$ & $<10$ & 10 \\
\hline As & 12 & 6 & 5 & $\mathrm{Pd}$ & $<1$ & $<1$ & 1 \\
\hline $\mathrm{U}$ & 3.1 & 2.6 & 0.5 & $\mathrm{Au}$ & $<5$ & $<5$ & 5 \\
\hline Th & 5.8 & 5.3 & 0.5 & $w t \%$ & & & \\
\hline V & 250 & 260 & 10 & $\mathrm{Si}$ & 15.6 & 14.5 & 0.01 \\
\hline $\mathrm{Zr}$ & 39 & 43 & 0.5 & $\mathrm{Fe}$ & 29.60 & 27.88 & 0.01 \\
\hline Sc & 51 & 50 & 1 & $\mathrm{Al}$ & 2.81 & 3.97 & 0.01 \\
\hline $\mathrm{La}$ & 20 & 16 & 0.5 & $\mathrm{Ti}$ & 0.07 & 0.17 & 0.001 \\
\hline $\mathrm{Ce}$ & 39 & 27 & 5 & $\mathrm{Mg}$ & 3.70 & 5.15 & 0.01 \\
\hline $\mathrm{Nd}$ & 10 & 10 & 10 & $\mathrm{Ca}$ & 2.58 & 3.97 & 0.01 \\
\hline $\mathrm{Sm}$ & 2.3 & 3.3 & 0.5 & $\mathrm{Na}$ & 0.08 & 0.07 & 0.01 \\
\hline $\mathrm{Eu}$ & 1.0 & 1.3 & 0.05 & K & 0.30 & 0.29 & 0.01 \\
\hline $\mathrm{Tb}$ & $<0.5$ & $<0.5$ & 0.5 & $S$ & 0.16 & 0.17 & 0.05 \\
\hline
\end{tabular}

However, preliminary results have shown that the $\mathrm{Cr}(\mathrm{VI})$ concentrations in water leachates from the metallurgical residue (slag) of Fe-Ni laterite samples from Lokris were very low (below $1 \mu \mathrm{g} / \mathrm{L}$ ) [31].

\subsubsection{Concentrations of $\mathrm{Cr}(\mathrm{VI})$ in Water Leachates for Fe-Ni Laterites and Bauxite Laterites}

Preliminary results of the water leaching experiments for Fe-Ni laterite ores have shown very low $\mathrm{Cr}(\mathrm{VI})$ concentrations in the samples from Lokris and up to $1200 \mu \mathrm{g} / \mathrm{L}$ $\mathrm{Cr}(\mathrm{VI})$ in samples from the Kastoria deposit [31]. Further leaching experiments carried out in the present study for Fe-Ni laterite deposits from the Balkan Peninsula showed significant $\mathrm{Cr}(\mathrm{VI})$ concentrations in certain laterites from $\mathrm{W}$. Vermion, the Bitincka, and Guri- Pergjegjum (Albania) deposits and bauxite laterite samples from the lowest parts of the Nissi deposit at Lokris (Table 7). 
Table 7. Concentrations of $\mathrm{Cr}(\mathrm{VI})$ in water leachates for Fe-Ni laterites and bauxite laterites from the Balkan Peninsula. Present study and [31]. Symbol * = samples analyzed in a previous study.

\begin{tabular}{|c|c|c|c|c|c|}
\hline Location & $\begin{array}{c}\text { Sample } \\
\text { I.D. }\end{array}$ & $\begin{array}{l}\mathrm{Cr}(\mathrm{VI}) \\
(\mu \mathrm{g} / \mathrm{L})\end{array}$ & Location & $\begin{array}{c}\text { Sample } \\
\text { I.D. }\end{array}$ & $\begin{array}{l}\mathrm{Cr}(\mathrm{VI}) \\
(\mu \mathrm{g} / \mathrm{L})\end{array}$ \\
\hline Kastoria & & & Guri-Pergjegium & & \\
\hline \multirow[t]{3}{*}{ Pisolitic z. } & $\mathrm{Ka}-7$ * & 750 & Pisolitic z. & G.P.40 & 40 \\
\hline & Ка-6 & 460 & & G.P.41 & 50 \\
\hline & Ka-5 & 500 & & & \\
\hline Goethite z. & $\mathrm{Ka}-4$ * & 1200 & Goethite z. & G.P.39 & 60 \\
\hline W. Vermion & & & Lokris & & \\
\hline \multirow[t]{3}{*}{ Pisolitic z. } & W.V5 & 7 & Laterite & LT-18* & 1.8 \\
\hline & W.V.6 & 26 & & LN-12 * & 1.3 \\
\hline & W.V.P2 & 12 & & LN-15 * & 0.6 \\
\hline Goethite z. & W.V.4 & $<4$ & & $\mathrm{LN}-1$ * & 0.7 \\
\hline Bitincka & & & Bauxite laterite & LAR.4 & 140 \\
\hline \multirow[t]{4}{*}{ Pisolitic z. } & $\mathrm{Bi} 43$ & 27 & & N3A & 10 \\
\hline & $\mathrm{Bi} 44$ & 90 & & N3B & 21 \\
\hline & Bi45 & 17 & & $\mathrm{~N}-9 \mathrm{~A}$ & 200 \\
\hline & & & & $\mathrm{N}-9 \mathrm{~B}$ & 60 \\
\hline \multirow[t]{2}{*}{ Goethite z. } & Bi47 & 4 & & N-P1 & 24 \\
\hline & & & & N-P2 & 66 \\
\hline
\end{tabular}

\section{Discussion}

The development of critical elements' production from local sources is considered to be crucial in view of the future needs of industry in the EU [1]. The investigation of critical metals in the frame of research projects, including the ProMine databases and EURARE provide geological information and mineral resources for mineral deposits, mines, and mining wastes and their assessment in relation to the importance of laterites for the EU economy $[1-8,27]$. Although the production of Co in Europe is derived from magmatic sulfide deposits, volcanogenic massive sulfides (VMS), hydrothermal deposits, and the black shale-hosted deposit in Finland and Sweden, the Fe-Ni-Co laterite deposits may be a potential resource for Co as well $[6,9,11]$.

\subsection{Cobalt Potential in Fe-Ni Laterites and Genesis of Co-Bearing Minerals}

In hydrous $\mathrm{Mg}$ silicate type of deposits $\mathrm{Ni}$ and $\mathrm{Co}$ are higher in the lower part of the saprolite, where nickel is hosted by Ni-bearing layer silicates, often referred to as garnierite and $\mathrm{Al}-\mathrm{Ni}-\mathrm{Co}-\mathrm{Mn}$ silicates [23,38]. The best-known example of this sub-type is the Goro deposit in New Caledonia, which has a resource of 323 million tons, grading $0.11 \%$ Co and $1.48 \% \mathrm{Ni}$ [11]. In the clay silicate sub-type of laterites, $\mathrm{Ni}$ and $\mathrm{Co}$ are enriched in clay minerals such as saponite and smectite in the mid to transition zone between the saprolite and the limonite zone. Murrin Murrin in Western Australia is a good example of a large $\mathrm{Ni}-\mathrm{Co}$ deposit of this type. It has a combined resource of 231 million tons, grading $1.01 \% \mathrm{Ni}$ and $0.08 \%$ Co [39]. However, in the Balkan Peninsula and Turkey, Co grades and tonnages are low compared to other deposits in New Caledonia, Australia, and Cuba [9].

The Fe-Ni laterite deposits in Greece account for about $80 \%$ of the nickel production in the the Balkan Peninsula [40], while the Co reserves reported for the $\mathrm{Fe}-\mathrm{Ni}-\mathrm{Co}$ laterite deposits in Greece contain almost 50,000 tons, including the Lokris, Evia, and Kastoria deposits [22,41]. The cobalt contents in Fe-Ni laterite deposits of the Balkan Peninsula rane from 180 to $1600 \mathrm{mg} / \mathrm{kg}$ Co and reach values over $3100 \mathrm{mg} / \mathrm{kg}$ Co at the lowest contact of the Lokris bauxite laterite deposit with the carbonate basement, which also yield the highest $(0.8 \mathrm{wt} \%) \mathrm{Mn}$ content (Table 2). In the Kastoria laterite deposit and at the lowermost parts of the Lokris $\mathrm{Fe}-\mathrm{Ni}$ laterite and bauxite laterite deposits, the highest Co, Mn, and Ni contents (Table 2 and Figure 7) are mostly hosted in Ni-Co lithiophorite replaced commonly by asbolane and manganomelane, which are more abundant towards fractures $[15,17,18,24,29]$. 
The presence of fragmented (Co, Mn, Ni)-hydroxides cemented by secondary silicates at E. Vermion and the replacement of serpentine by Ni serpentine (Figure 6) suggest that the $\mathrm{Ni}$ enrichment event post-dated that of the $(\mathrm{Co}, \mathrm{Ni}, \mathrm{Mn})(\mathrm{OH})_{2}$ fragmentation. There is a wide compositional variation in the $(\mathrm{Co}, \mathrm{Mn}, \mathrm{Ni})(\mathrm{OH})_{2}$ and an excellent negative correlation between $\mathrm{MnO}$ and the sum $(\mathrm{CoO}+\mathrm{NiO})($ Table 1; Figure 7) with the highest $\mathrm{Co}$ content (54 wt\% CoO) of an unknown Co-hydroxide occurring towards the central parts of the concentric aggregates (Figure 6). Those (Co, Mn, Ni)-hydroxides appear clearly postdated the transformation (schistosity) of main Fe-Ni laterite ore (Figure 6). The occurrence of the nickel hydroxides $\left[\mathrm{Ni}(\mathrm{OH})_{2}\right]$ in nature is rare. Theophrastite and $\mathrm{Ni}(\mathrm{OH})_{2}$ were discovered in the metamorphosed laterites of the E. Vermion [35], and subsequently, it was described in chromitites from the Hagdale Quarry, Unst, Shetland Islands [42]; in nickel ores of the Lord Brassey mine, Tasmania, Australia [43]; and elsewhere [44]. Although a significant mutual substitution of $\mathrm{Mn}^{2+}, \mathrm{Ni}^{2+}$, and $\mathrm{Co}^{2+}$ is facilitated in those hydroxides, due to the similarity in their ionic radius, $\mathrm{Co}^{2+}(0.72 \AA), \mathrm{Ni}^{2+}(0.69 \AA)$, and $\mathrm{Mn}^{2+}(0.80 \AA)$, they are very rare in nature [45]. The association of $(\mathrm{Co}, \mathrm{Mn}, \mathrm{Ni})(\mathrm{OH})_{2}$ and $\mathrm{Ni}(\mathrm{OH})_{2}$ in the studied deposits may reflect a common origin, subsequently of a strong late tectonic evolution, which obscures earlier deformation events. The formation processes of the Ni-hydroxide have been attributed to alkaline (in the $\mathrm{pH}$ region of 7 to 8 ) conditions due to the neighboring limestone and to the low temperature $\left(<200{ }^{\circ} \mathrm{C}\right)[46]$. However, the extremely tiny crystal size of these hydroxides and the unnamed Co-dominant hydroxide require further research and interpretation.

\subsection{The Co, Mn-Zn-Bearing Fe Chromite}

A (Mn, Zn, Co) enrichment in the Fe chromite of zoned chromite grains (Figure $5 \mathrm{~g}, \mathrm{~h}$ ), due to the substitution of $\mathrm{Mg}^{2+}$ and $\mathrm{Fe}^{2+}$ by $\mathrm{Mn}, \mathrm{Zn}$, and $\mathrm{Co}$ in the chromite lattice (Figure 4i), has been recorded only in certain Ni laterite deposits and has been attributed to the availability of $\mathrm{Mn}^{2+}, \mathrm{Zn}^{2+}$, and $\mathrm{Co}^{2+}$ in solution and to the Eh and $\mathrm{pH}$ conditions, probably during diagenetic and meta-diagenetic stages of the laterite ore [19]. The lack of any significant $\mathrm{Mn}, \mathrm{Zn}$, or Co enrichment and Fe chromite along cracks or peripheral parts (Figure 5c,e) of chromite hosted in laterite ores from the Palaochori and Katjeli deposits, hosting abundant fossilized organic matter (Figure $5 a, b, d$ ) may reflect a significant role of the organic matter in the reduction of metals (Figure 5i). Nevertheless, the small portion of chromite grains or fragments in Fe-Ni laterites and the occurrence of elevated Co in small Fe-chromite zones of certain laterite occurrences only (E. Vermion, Olympos, Edessa, Skyros Island) suggest that they must be considered a negligible source for Co production.

\subsection{REE and Sc Potential and Their Genetic Significance}

The highest productive potential of REE in the EU is recognized for alkaline igneous rock deposits (Sweden, Greenland/Denmark), while a smaller potential is known for skarn hydrothermal deposits and iron oxide-apatite deposits (in Sweden). Small carbonatite deposits are known in Finland and Germany, while small placer deposits are located in Spain [1,8]. In general, karst-type Fe-Ni laterites display REE contents ranging from a few tens to thousands of $\mathrm{mg} / \mathrm{kg}$, depending on the site of the Ni laterite samples along vertical profiles and on the post-deposition processes that affect their composition. Specifically, the Fe-Ni laterites lying on peridotites such as the Kastoria, Bitincka, and Guri-Pergjegjum (Albania) deposits show a low REE content, in contrast to the lowest part of the Lokris deposit lying on karstified Jurassic limestone, exhibiting an enrichment in $\Sigma$ REE, reaching values over $6000 \mathrm{mg} / \mathrm{kg} \Sigma \mathrm{REE}, 66 \mathrm{mg} / \mathrm{kg} \mathrm{U}, 25 \mathrm{mg} / \mathrm{kg}$ Th, and $1800 \mathrm{mg} / \mathrm{kg}$ As (Table 2). Such elevated REE content, along with $\mathrm{Co}, \mathrm{Mn}$, and $\mathrm{Ni}$, may indicate the mobilization of these metals under reducing and acidic conditions, and subsequently, redeposition under alkaline conditions at the lowest parts at the contacts between laterites and carbonate rocks, which is supported by the presence of the authigenic REE minerals (hydroxyl)bastnaesite$(\mathrm{Nd})$ and $(\mathrm{La}, \mathrm{Nd}, \mathrm{Y})$ bastnaesite at the Lokris deposit (Figure 3e,f); [26,30]. 
The difference between the REE patterns of the laterite samples from the lowest part with a negative Ce anomaly and the upper parts of the Lokris deposit with positive Ce anomalies (Figure 10a) may reflect the oxidation of $\mathrm{Ce}^{3+}$ to $\mathrm{Ce}^{4+}$ and its incorporation into other Ce-rich minerals [26]. In addition, a good positive correlation between the $\Sigma$ REE and $\mathrm{P}_{2} \mathrm{O}_{5}$ content (Figure 12e) may suggest the existence of secondary phosphate minerals in the Vermion laterites, which have a significant $\mathrm{P}_{2} \mathrm{O}_{5}$ content (Tables 3 and 4). Thus, $\mathrm{Fe}-\mathrm{Ni} \pm$ Co laterites in the Balkan Peninsula may contain a significant REE potential, but it is probably controlled by the redox and $\mathrm{pH}$ conditions during the mobilization and reprecipitation processes that caused metal leaching and residual enrichment throughout deposit profiles and REE concentration at the lowest parts of the deposits [26,30,47].

Scandium, another critical element, is classified as a rare earth element by the International Union of Pure and Applied Chemistry, but although all the other REEs are present in certain deposits, the Sc content may be insignificant [48]. Due to the similarity of the Sc ionic radius with that of $\mathrm{Mg}^{2+}$ and $\mathrm{Fe}^{2+}$, which is smaller than that of any other $\mathrm{REE}$, it is mainly hosted in clinopyroxenes, in contrast to the REE-minerals [48]. After pyroxene breakdown, $\mathrm{Sc}$ is released into percolating water where it is transported and exhibits a positive correlation with $\mathrm{Fe}_{2} \mathrm{O}_{3}$ (Figure 9), suggesting its association with the Fe-oxides in laterites. It is low $(0.6$ to $12 \mathrm{mg} / \mathrm{kg})$ in weathered peridotites and saprolite zones, but in laterite ores, it varies from 41 to $79 \mathrm{mg} / \mathrm{kg}$ (average $60 \mathrm{mg} / \mathrm{kg}$ ) (Tables 2-5) [16,18,49]. Higher Sc contents, about $120 \mathrm{mg} / \mathrm{kg}$ (average approximately $70-80 \mathrm{mg} / \mathrm{kg} \mathrm{Sc}$ ) have been recorded in the Fe-Ni laterites from Cuba and the Dominican Republic [12]. Thus, assuming that Sc can be produced as a by-product of metallurgical processes or from tailings and residues $[49,50]$, resources with more than $20 \mathrm{mg} / \mathrm{kg}$, such as Fe-Ni laterites from the Balkan Peninsula can be considered as a Sc source.

\subsection{Genetic and Economic Significance of PGE}

The total PGE contents in Fe-Ni laterites around the world are in the range of less than $100 \mu \mathrm{g} / \mathrm{kg}$ to up to a few hundred $\mu \mathrm{g} / \mathrm{kg}$ [51,52]. However, lateritic crust with $2 \mathrm{mg} / \mathrm{kg}$ PGE over the Ora Banda Sill in Western Australia has been reported [53], as well as more than $4 \mathrm{mg} / \mathrm{kg}$ PGE from Burundi [54]. In general, the platinum-group element (PGE) content, reaching up to $88 \mu \mathrm{g} / \mathrm{kg} \mathrm{Pt}$ and $186 \mu \mathrm{g} / \mathrm{kg} \mathrm{Pd}$ is higher in $\mathrm{Fe}-\mathrm{Ni} \pm$ Co laterites than in bauxite laterites (Tables 2-5 and Figure 11d-f), bauxites [37], and chromite concentrates from ultramafic rocks [55]. A common feature of the studied deposits from the Balkan Peninsula, including two Fe-Ni laterite profiles from the Gouri-Perjuegjiun and Bitincka deposits of Albania, the Kastoria, and W. Vermion, is the higher Pt than Pd contents, higher $(\mathrm{Pt}+\mathrm{Pd})$ contents in ores compared to parent peridotites, and their concentration mostly in the pelitomorphic and pisolitic-oolitic types (Tables 2-5) [16,18]. Although PGE-bearing or PGE minerals were not identified yet in laterites of the Balkan Peninsula, the elevated PGE content in those laterites, and the presence of PGE-bearing mineral compounds at the border of secondary Fe oxide(s) grains elsewhere [12] support the PGEs' mobility during weathering [56-60]. The higher solubility and mobility of Pd compared to that of Pt [61] may be reflected in the observed decoupling between $\mathrm{Pt}$ and $\mathrm{Pd}$ in the allochthonous laterites, as is exemplified by the higher value of the $\mathrm{Pt} / \mathrm{Pd}$ ratio in the laterite deposits than in the lowermost part of the Lokris deposit (Table 2). In addition, it has been suggested that high Eh (0.3-1.11 V) and low pH (3-5) conditions caused the mobility of PGEs with subsequently incorporation into Fe oxides in laterites of southeast Cameroon [52]. The occurrence of secondary PGM in laterite profiles support the mobilization of PGEs during weathering, lateritization, and post-depositional processes [12,18]. Thus, the existence of high Pt and Pd (up to $88 \mu \mathrm{g} / \mathrm{kg}$ Pt and $186 \mu \mathrm{g} / \mathrm{kg} \mathrm{Pd}$ ) in laterite samples from the Balkan Peninsula, which are much higher compared to those in typical chromitites [62], may be related to the mobilization of PGEs during weathering, lateritization, and post-depositional processes. In addition, the chromium isotope data for laterite are limited, laterite samples from the Lokris and Kastoria deposits have shown highly variable $\delta^{53} \mathrm{Cr}$ values ranging from -0.2 in the former to $1.08 \%$ in the latter, while the average $(n=3)$ of the $\delta^{53} \mathrm{Cr}$ values 
in water leachates was $0.79 \%$ for weathered ultramafic rocks [31], showing a negative correlation with the Pt content (Figure 13).

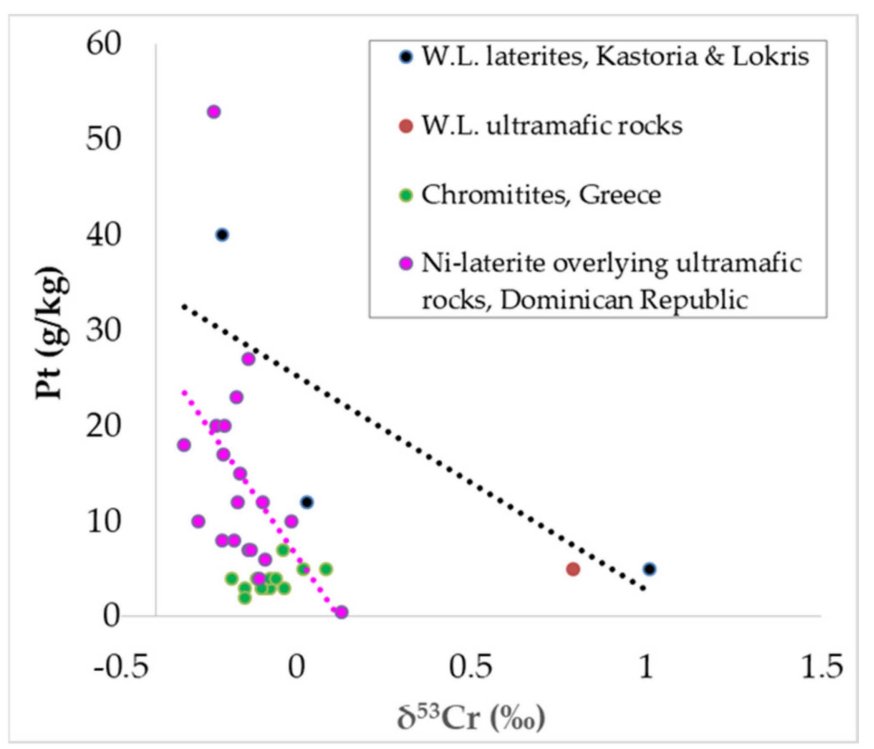

Figure 13. Plot of $\mathrm{Pt}$ versus $\delta^{53} \mathrm{Cr}$ values for $\mathrm{Fe}-\mathrm{Ni} \pm \mathrm{Co}$ laterites, chromitites, and weathered ultramafic rocks from Greece and the Dominican Republic. Data from [12,31,63].

Therefore, the redox processes have a significant effect on the $\mathrm{Cr}$ isotope fractionation and the Pt distribution in laterites. The low Pt contents and the low $\delta^{53} \mathrm{Cr}$ values in chromitites may reflect mostly magmatic conditions (less redistribution), while the low $\delta^{53} \mathrm{Cr}$ values and the relatively high $\mathrm{Pt}$ content in the Kastoria laterites suggest oxidation of $\mathrm{Cr}$ to $\mathrm{Cr}(\mathrm{VI})$ during the redeposition of the laterite ore, the adsorption on goethite, and the limited back-reduction to $\mathrm{Cr}(\mathrm{III})$. Assuming that during the reduction of the $\mathrm{Cr}(\mathrm{VI})$ to $\mathrm{Cr}(\mathrm{III})$ the lighter chromium isotopes $\left({ }^{52} \mathrm{Cr}\right)$ are preferentially reduced, an enrichment of ${ }^{53} \mathrm{Cr}$ relative to the values of ${ }^{52} \mathrm{Cr}$ is recorded [29]. Thus, the lower Pt content and higher $\delta^{53} \mathrm{Cr}$ values in the Lokris deposits may indicate that $\mathrm{Cr}$ released from parent ultramafic rocks and oxidized to $\mathrm{Cr}(\mathrm{VI})$ due to the presence of Mn-oxides [64] was subsequently back-reduced to $\mathrm{Cr}(\mathrm{III})$ under more reductive conditions [29,65].

\section{Environmental Risk from Laterite Ores}

The environmental impact from metals/metalloids may be related to the mineralogical and geochemical characteristics of the ore, the effect during mining, pre-concentration, and smelting processes of $\mathrm{Fe}-\mathrm{Ni}$ laterite ores. High Co concentrations have been reported in mine waters and groundwater related to the weathering and dissolution of Co-bearing sulfide ores and secondary minerals in regions of acidic $\mathrm{pH}$, while in water flowing from the leach plant at $\mathrm{pH} 2.9$ may occur up to $34,400 \mathrm{mg} / \mathrm{L} \mathrm{Cr}(\mathrm{VI})$ [66]. With exception of the Bou Azzer deposit, where Co is the chief commodity [66], Co is almost always mined as a by-product, including the $\mathrm{Fe}-\mathrm{Ni}$ laterite deposits, the main product being $\mathrm{Ni}$ and $\mathrm{Cu}$, depending on the deposit type $[66,67]$. Cobalt's aqueous geochemistry is dominated by +2 and +3 oxidation states, with $\mathrm{Co}^{3+}$ being thermodynamically unstable and changing under Eh-pH conditions [67]. Mining activity and the associated Co-bearing wastes are potential sources of contamination by Co. However, knowledge gaps include the mechanism and kinetics of secondary Co-bearing mineral transformation, the extent at which such environmental cycling is facilitated by microbial activity, the nature of Co speciation across different Eh-pH conditions and Co toxicity for human/ecosystems [66-68]. 


\subsection{Environmental Impact from Mining/Smelting Processes}

The soil contamination by heavy metals $(\mathrm{Cr}, \mathrm{Fe}, \mathrm{Mn}$, and $\mathrm{Co})$ due to the weathering/alteration of laterite deposits and parent ultramafic rocks, mining, and large volumes of smelting residues (slag) and their transfer into groundwater and plants/crops is common in many countries of the world [31,51,63-65,69].

Available data on the bioavailability and bioaccumulation of metal in C. Evia and the Assopos-Thiva Basins contaminated by weathered ophiolites/laterite mining, agricultural, and industrial activities have shown that the $\mathrm{Cr}$ content in plants/crops (dry weight) ranges from $<1$ to tens of $\mathrm{mg} / \mathrm{kg}$, and it is higher in the roots compared to being poorly transported to the shoots [69]. Another threat from the exploitation of Fe-Ni laterites may be fine particles with a diameter of less than 10 microns (PM10) and of 2.5 microns or less (2.5 PM), which are considered to be among the greatest health risk since they are deposited and remain within the respiratory system [70]. The measuring and monitoring of PM10 and PM2.5 particles with distance from the dust source is required for the establishment of background particulate levels to be used in the air quality modelling and health protection. The processing for the production of Fe-Ni alloys at the Larymna plant is accompanied by the production of millions of tons of slag and the emission of tons of fly ash and fine dust collected in the anti-pollution systems [40]. The detailed investigation of slag and fly ash from laterite smelting (Niquelandia, Brazil) has shown that leaching was highly $\mathrm{pH}$-dependent for both slag and fly ash, the highest releases of harmful elements occurred between $\mathrm{pH} 3$ and 7 , and the fly ash was significantly more reactive, suggesting that the disposal sites for the fly ash can represent a significant source of local pollution [70,71].

\subsection{The $\mathrm{Cr}(\mathrm{VI})$ Concentrations in Water Leachates from $\mathrm{Fe}-\mathrm{Ni} \pm \mathrm{Co}$ Laterites}

Although $\mathrm{Cr}(\mathrm{III})$ is a required nutrient, the form of oxidized $\mathrm{Cr}(\mathrm{VI})$ is highly toxic, very soluble, and causes serious health problems [72]. Thus, further $\mathrm{Cr}(\mathrm{VI})$ concentrations in water leachates for the majority of $\mathrm{Fe}-\mathrm{Ni}$ laterites were determined. The groundwater from Neogene shallow aquifers (10-100 m) throughout C. Evia (Messapia), characterized by the extensive presence of ultramafic rocks and $\mathrm{F}-\mathrm{Ni}$ laterite deposits, contains over the maximum acceptable level for $\mathrm{Cr}_{\text {total }}$ in drinking water $(50 \mu \mathrm{g} / \mathrm{L})$, reaching up to $360 \mu \mathrm{g} / \mathrm{L}$ $\mathrm{Cr}(\mathrm{VI})$ in irrigation water [63,69]. In addition, relatively high $\mathrm{Cr}(\mathrm{VI})$ concentrations are known in the leachates of $\mathrm{Fe}-\mathrm{Ni}$ laterites from the Kastoria deposit [31]. The present study revealed significant $\mathrm{Cr}(\mathrm{VI})$ concentrations in leachates from the Gouri-Perjuegiiun and Bitincka deposits of Albania and the W. Vermion laterites, all lying on weathered peridotites, as well as in bauxite laterites from the Nissi-Patitira deposit (Table 7). The latter bauxite laterite samples come from highly tectonized zones, towards the contact of the deposit with carbonate basement, commonly grading from red to a gray, pinkish-white color (Figure 4a). They are characterized by hundreds of $\mathrm{mg} / \mathrm{kg}$ of As, elevated contents of REE and Co (Table 2), while in laterites from Kasroria, W. Vermion, Gouri-Perjuegjiun, and Bitincka deposits, the REE and As contents are relatively low (Tables 3 and 5). Since As in soil, plant/crops, and drinking water is a crucial contaminant for human health and ecosystems [72-74], the As oxidation state was studied in a bauxite laterite sample, by Synchrotron Radiation (SR) spectroscopic techniques, and it was found to be adsorbed exclusively onto goethite-type phases, occurring in the form of arsenate anions $\left(\mathrm{AsO}_{4}{ }^{3-}\right)$ [30]. Although there is still debate on whether the mineral is of direct organic or inorganic origin $[75,76]$, recent studies of the internal structure of framboids within a microbial biofilm suggest that the organic matrix may play a central role in the nucleation of pyrite microcrystals that form framboids $[77,78]$.

\subsection{The Role of Organic Matter into Biomobilization and Biomineralization}

In general, the presence of organic matter and microorganism traces in highly tectonized zones of the metamorphosed Fe-Ni laterites (Figures 3-6) may suggest the direct involvement of microorganisms and appropriate conditions for metal bioleaching and biomineralization [24,79-87]. It is well known that microorganisms of varying morphologi- 
cal forms produce enzymes which are considered to be a powerful factor to catalyze redox reactions and act as nucleation sites for the precipitation of secondary minerals [83-87]. The negative $\delta^{34} \mathrm{~S}$ values $(-25.0 \%$ to $-26.2 \%$ ) [24] for sulfide-bearing samples and the presence of bacterio-morphic goethite in the Lokris deposit (Figure 3) have been suggested to reflect the existence of the appropriate conditions for metal bioleaching and biomineralization [24]. This review highlights that the occurrence of organic matter is a common feature in many laterite deposits of the Balkan Peninsula, such as a sequence of carbon-rich mudstones in Lokris and elsewhere [15], the Kastoria deposit (Figure 3), the Paleochori and Katjeli deposits (Figure 5), and the E. Vermion metamorphosed laterite occurrence (Figure 6). In addition, the Katjeli Fe-Ni deposit is conformably overlain by a Tertiary series consisting of small beds of lignite and sandstone intercalations (Figure 2A). In the reworking of laterites, due to the repeated marine transgression/regressions and its deposition in a shallow marine environment $[15,17,18,24]$, microorganisms which reduce $\mathrm{Mn}(\mathrm{IV})$ and $\mathrm{Fe}(\mathrm{III})$ and use the gained energy for their growth $[88,89]$ may facilitate the dissolution of $\mathrm{Mn}(\mathrm{IV})$ and Fe(III) minerals under reducing and slightly acidic conditions, forming aqueous $\mathrm{Mn}(\mathrm{II})$ and $\mathrm{Fe}(\mathrm{II})$ [90].

The negatively charged surfaces of bacteria cells offer extensive surfaces for biosorption of metals where elements with a higher positive charge are preferentially adsorbed [80]. Both the metabolic activity and the biomineral precipitation by organisms may play an important role in trace element co-precipitation $[77,81,82]$. Thus, the described bacteriomorphic goethite at the Nissi-Patitira deposits, coupled with the negative $\delta^{34} S$ values for sulfide-bearing samples towards the top of the deposit [24] may suggest the existence of the appropriate conditions for iron bioleaching, the top-down remobilization of the laterite deposit, and the biomineralization at the contact with the carbonate basement [24]. The existence of significant As only in bacteriomophic goethite type in the Patitira-Nissi deposits [26] and the presence of $\mathrm{Cr}(\mathrm{VI})$ in water leachates from such ore samples may reflect that both bacteria and chemical processes may be invoked in the As and $\mathrm{Cr}$ redox reactions, and the need for monitoring of the $\mathrm{Cr}(\mathrm{VI})$ content in groundwater aquifers affected by the mining of $\mathrm{Fe}-\mathrm{Ni}$ laterites. In addition, a quantitative relationship between the $\mathrm{Cr}(\mathrm{VI})$ production rates and $\mathrm{Cr}(\mathrm{III})$ solubility of $\mathrm{CrxFe}_{1-x}(\mathrm{OH})_{3}$ has been established in an attempt to predict $\mathrm{Cr}(\mathrm{VI})$ production rates at different conditions [81]. These authors showed that soluble $\mathrm{Cr}(\mathrm{III})$ released from $\mathrm{CrxFe}_{1-\mathrm{x}}(\mathrm{OH})_{3}$ solids to aqueous solution can migrate to $\mathrm{MnO}_{2}$ surfaces and provide a major geochemical pathway for $\mathrm{Cr}(\mathrm{VI})$ occurrence from $\mathrm{Cr}(\mathrm{III})$ in groundwater, soils, or sub-seafloor environments.

Therefore, the association on ( $\mathrm{Mn}, \mathrm{Ni}, \mathrm{Co})$-hydroxides with fossilized organic material (Figures 3-6) may indicate that microbial metal cycling play an important role in controlling the mobility of $\mathrm{Co}, \mathrm{Ni}, \mathrm{REE}, \mathrm{Sc}$, and PGE downward and their redeposition under alkaline conditions, probably during post-depositional and diagenesis stages. Based on such evidence on the biogeochemical cycling of $\mathrm{Co}, \mathrm{Mn}$, and $\mathrm{Ni}$ in several laterite deposits, new bioprocessing techniques have been proposed to recover these metals $[68,70,71]$. In addition, the investigation of the ability of organic matter in reducing $\mathrm{Cr}$ uptake by crops irrigated with $\mathrm{Cr}(\mathrm{VI})$ water provides a way for the restriction of $\mathrm{Cr}$ transfer to plants/crops from contaminated soils and irrigation water. Specifically, using organic matter in the form of leonardite (an oxidized form of lignite), due to its high content of humic acid, is considered to be a useful organic fertilizer that provides possibilities for combining food production with soil protection [91].

\section{Conclusions}

The presented data combined with the review of the available geological, mineralogi$\mathrm{cal}$, and geochemical features of $\mathrm{Fe}-\mathrm{Ni} \pm \mathrm{Co}$ laterites from the Balkan Peninsula led us to the following conclusions:

- The bulk ore analyses indicated that the $\mathrm{Fe}-\mathrm{Ni} \pm \mathrm{Co}$ laterites from the Balkan Peninsula are a potential source of nickel ranging from 0.21 to $3.5 \mathrm{wt} \% \mathrm{Ni}$, and of cobalt ranging from 0.03 to $0.31 \mathrm{wt} \% \mathrm{Co}$. In addition, an average content of $55 \mathrm{mg} / \mathrm{kg} \mathrm{Sc}$, 
which is more than $20 \mathrm{mg} / \mathrm{kg}$, and is considered as a Sc source suggests that laterites are a potential source of $\mathrm{Sc}$ as well.

- In general, the REE potential in the $\mathrm{Fe}-\mathrm{Ni} \pm \mathrm{Co}$ laterites of the Balkan Peninsula is relatively low, but metal-leaching and reprecipitation of REE at the lowest parts of the karst-type deposits, controlled by the redox and $\mathrm{pH}$ conditions, may result in a significant REE content.

- The existence of up to $88 \mu \mathrm{g} / \mathrm{kg}$ Pt and $186 \mu \mathrm{g} / \mathrm{kg}$ Pd in laterite samples from the Balkan peninsula, which are much higher compared to those in typical chromitites (the main collector of PGE in ophiolites) and the positive $\mathrm{Pt}-\mathrm{Fe}_{2} \mathrm{O}_{3}$ correlation in the goethite and pisolitic-oolitic zones of laterites, support the PGE mobilization during weathering, lateritization, and post-depositional processes.

- Present textural, mineralogical, and geochemical data on the Ni-Co laterite deposit from the Balkan Peninsula with elevated $\mathrm{Co}, \mathrm{Mn}$, and Ni have evolved through the redeposition and post-deposition processes rather than during lateritization.

- The association on ( $\mathrm{Mn}, \mathrm{Ni}, \mathrm{Co}$ )-hydroxides with fossilized organic material and the interelement relationships may indicate that microbial metal cycling play an important role in controlling their downward mobility and their redeposition under alkaline conditions, probably during post-depositional and diagenesis stages.

- The relatively high $\mathrm{Pt}$ content versus low $\delta^{53} \mathrm{Cr}$ values and high $\mathrm{Cr}(\mathrm{VI})$ concentrations in leachates from the Kastoria laterite samples suggest the oxidation of $\mathrm{Cr}$ to $\mathrm{Cr}(\mathrm{VI})$ during the redeposition of the laterite ore, the adsorption onto goethite, and the limited back-reduction to $\mathrm{Cr}$ (III). In contrast, the Lokris laterite deposits with lower Pt content exhibit higher ${ }^{53} \mathrm{Cr}$ values, suggesting that the oxidation of the released $\mathrm{Cr}$ from ultramafic rocks into $\mathrm{Cr}(\mathrm{VI})$ is followed by a back-reduction to $\mathrm{Cr}(\mathrm{III})$ under more reductive conditions.

- The bioaccumulation of $\mathrm{Cr}$ in contaminated soil and irrigation groundwater coupled with the elevated $\mathrm{Cr}(\mathrm{VI})$ concentrations in natural water leachates for $\mathrm{Fe}-\mathrm{Ni}$ laterite samples from the Kastoria, Bitincka, Guri-Pergjegjum, and Nissi-Patitira (Lokris) deposits point to the potential human health risk and environmental significance of an integrated water-soil-plant investigation of the $\mathrm{Cr}$ contamination in basins surrounding laterite mines.

Author Contributions: Conceptualization and methodology: M.E.-E., M.L. and D.G.E.; software and validation of data, writing-original draft preparation: M.E.-E., M.L., I.M., S.K. and G.D.E. All authors have read and agreed to the published version of the manuscript.

Funding: The financial support in the frame of the "Integrated Technologies for Minerals Exploration: Pilot Project for Nickel Ore Deposits" (Part of an EU BRITE EURAM III Project-Contract No. BE 1117 CT95-0052) is greatly acknowledged once again.

Acknowledgments: Many thanks are expressed to E. Michaelidis, University of Athens, for his assistance with the electron probe analyses. The criticism and constructive suggestions by two anonymous reviewers and the Editors Cristina Domènech and Cristina Villanova-de-Benavent are much appreciated.

Conflicts of Interest: The authors declare no conflict of interest.

\section{References}

1. European Commission. A New Industrial Strategy for Europe. Communication from the Commission to the European Parliament, the Council, the European Economic and Social Committee and the Committee of the Regions, COM(2020) 102 Final; European Commission: Brussels, Belgium, 2020.

2. Lewicka, E.; Guzik, K.; Galos, K. On the Possibilities of Critical Raw materials Production from the EU's Primary Sources. Resources 2021, 10, 50. [CrossRef]

3. Cassard, D.; Bertrand, G.; Billa, M.; Serrano, J.J.; Tourlière, B.; Angel, J.M.; Gaál, G. ProMine Mineral Databases: New Tools to Assess Primary and Secondary Mineral Resources in Europe. In 3D, 4D and Predictive Modelling of Major Mineral Belts in Europe; Weihed, P., Ed.; Springer: Cham, Switzerland, 2015. 
4. Cassard, D.; Tertre, F. Improvement of KDPs' Applications and Interaction with the RMIS and the GeoERA Information Platform. 2021. Available online: https://geoera.eu/wp-content/uploads/2021/03/D5.5-KDP\%E2\%80\%99s-applications-delivery-toRMIS.pdf (accessed on 30 May 2021).

5. Lauri, L.S.; Eilu, P.; Brown, T.; Gunn, G.; Kalvig, P.; Sievers, H. Identification and Quantification of Primary CRM Resources in Europe. 2018. Available online: http://scrreen.eu/wp-content/uploads/2018/03/SCRREEN-D3.1-Identification-andquantification-of-primary-CRM-resources-in-Europe.pdf (accessed on 22 March 2021).

6. Sadeghi, M.; Arvanitidis, N.; Ladenberger, A. Geochemistry of Rare Earth Elements in Bedrock and Till, Applied in the Context of Mineral Potential in Sweden. Minerals 2020, 10, 365. [CrossRef]

7. Minerals4EU. Available online: http:/ / www.minerals4eu.eu/ (accessed on 17 March 2021).

8. Goodenough, K.M.; Schilling, J.; Jonsson, E.; Kalvig, P.; Charles, N.; Tuduri, J.; Deady, E.A.; Sadeghi, M.; Schiellerup, H.; Mueller, A.; et al. Europe's rare earth element resource potential: An overview of REE metallogenic provinces and their geodynamic setting. Ore Geol. Rev. 2016, 72, 838-856. [CrossRef]

9. Horn, S.; Gunn, A.G.; Petavratzi, E.; Shaw, R.A.; Eilu, P.; Törmänen, T.; Bjerkgård, T.; Sandstad, J.S.; Jonsson, E.; Kountourelis, S.; et al. Cobalt resources in Europe and the potential for new discoveries. Ore Geol. Rev. 2021, 130, 103915. [CrossRef]

10. Mudd, G.M. Global trends and environmental issues in nickel mining: Sulfides versus laterites. Ore Geol. Rev. 2010, 38, 9-26. [CrossRef]

11. Berger, V.I.; Singer, D.A.; Bliss, J.D.; Moring, B.C. Ni-Co Laterite Deposits of the World-Database and Grade and Tonnage Models; USGS Open-File Report: Menlo Park, CA, USA, 2011; Volume 1058, p. 26.

12. Aiglsperger, T.; Proenza, J.A.; Zaccarini, F.; Lewis, J.F.; Garuti, G.; Labrador, M.; Longo, F. Platinum-group minerals (PGM) in the Falcondo Ni-laterite deposit, Loma Caribe peridotite (Dominican Republic). Mineral. Depos. 2015, 50, 105-123. [CrossRef]

13. Freyssinet, P.; Butt, C.R.M.; Morris, R.C.; Piantone, P. Ore-forming processes related to lateritic weathering. Econ. Geol. 100th Anniv. Vol. 2005, 2005, 681-722.

14. Milushi, I. An Overview of the Albanian Ophiolite and Related Ore Minerals. Acta Geol. Sin. 2015, 89, 61-64. [CrossRef]

15. Valeton, I.; Biermann, M.; Reche, R.; Rosenberg, F. Genesis of Nickel laterites and bauxites in Greece during the Jurassic and Cretaceous, and their relation to ultrabasic parent rocks. Ore Geol. Rev. 1987, 2, 359-404. [CrossRef]

16. Tashko, A.; Laskou, M.; Eliopoulos, D.; Economou-Eliopoulos, M. The behavior of Pt, Pd, and Au during lateritization process of the ultramafic rocks of the Shebenic-Pogradec massif, Albania: Plate tectonic aspects of the Alpine metallogeny in the Carpatho-Balkan region. In Proceedings of the Annual Meeting of IGCP Project 356, Sofia, Bulgaria, December 1996; pp. 121-131.

17. Alevizos, G. Mineralogy, Geochemistry and Origin of the Sedimentary Fe-Ni Ores of Lokris. Ph.D. Thesis, Technical University of Crete, Chania, Greece, 1997; p. 245.

18. Eliopoulos, D.; Economou-Eliopoulos, M. Geochemical and mineralogical characteristics of Fe-Ni and bauxitic-laterite deposits of Greece. Ore Geol. Rev. 2000, 16, 41-58. [CrossRef]

19. Economou-Eliopoulos, M. Apatite and Mn, Zn, Co-enriched chromite in Ni-laterites of northern Greece and their genetic significance. J. Geochem. Explor. 2003, 80, 41-54. [CrossRef]

20. Boev, B.; Jovanovski, G.; Makreski, P. Minerals from Macedonia. XX. Geological setting, lithologies, and identification of the minerals from Rzanovo Fe-Ni deposit. Turk. J. Earth Sci. 2009, 18, 631-652. [CrossRef]

21. Thorne, R.; Herrington, R.J.; Roberts, S. Composition and origin of the Çaldağ oxide nickel laterite, W. Turkey. Miner. Depos. 2009, 44, 581-595. [CrossRef]

22. Eliopoulos, D.G.; Economou-Eliopoulos, M.; Apostolikas, A.; Golightly, J.P. Geochemical features of nickel-laterite deposits from the Balkan Peninsula and Gordes, Turkey: The genetic and environmental significance of arsenic. Ore Geol. Rev. 2012, 48, 413-427. [CrossRef]

23. Golightly, J.P. Progress in understanding the evolution of nickel lateritics. In The Challenge of Finding New Mineral Resources—Global Metallogeny, Innovative Exploration, and New Discoveries; Goldfarb, R.J., Marsh, E.E., Monecke, T., Eds.; Economic Geologogy. Special Publication 15; Society of Economic Geologists, Inc.: Littleton, CO, USA, 2010; Volume 15, pp. 451-486.

24. Kalatha, S.; Economou-Eliopoulos, M. Framboidal pyrite and bacteriomorphic goethite at transitional zones between Fe-Nilaterites and limestones: Evidence from Lokris, Greece. Ore Geol. Rev. 2015, 65, 413-425. [CrossRef]

25. Skarpelis, N.; Laskou, M.; Alevizos, G. Mineralogy and geochemistry of the nickeliferous lateritic iron-ores of Kastoria, N.W. Greece. Chem. Erde 1993, 53, 331-339.

26. Kalatha, S.; Perraki, M.; Economou-Eliopoulos, M.; Mitsis, I. On the origin of bastnaesite-(La,Nd,Y) in the Nissi (Patitira) bauxite laterite deposit, Lokris, Greece. Minerals 2017, 7, 45. [CrossRef]

27. Baker, J.; Cassard, D.; Grundfelt, B.; Ehinger, S.; D’Hugues, P.; Gaál, G.; Kaija, J.; Kurylak, W.; Mizera, W.; Sarlin, J.; et al. A New Approach to Mineral Resources in Europe-ProMine. In Proceedings of the Sustainable Production and Consumption of Mineral Resources-Integrating the EU's Social Agenda and Resource Efficiency-FP7 Cooperation Work Programme, 2013, Theme 4, NMP-2008-4.0, Wroclav, Poland, 20-22 October 2011.

28. Saccani, E.; Photiades, A.; Santato, A.; Zeda, O. New evidence for supra-subduction zone ophiolites in the Vardar Zone from the Vermion Massif (northern Greece): Implication for the tectono-magmatic evolution of the Vardar oceanic basin. Ofioliti 2008, 33, 17-37.

29. Ellis, A.S.; Johnson, T.M.; Bullen, T.D. Chromium isotopes and the fate of hexavalent chromium in the environment. Science 2002, 295, 2060-2062. [CrossRef] 
30. Gamaletsos, P.N.; Kalatha, S.; Godelitsas, A.; Economou-Eliopoulos, M.; Göttlicher, J.; Steininger, R. Arsenic distribution and speciation in the bauxitic Fe-Ni-laterite ore deposit of the Patitira mine, Lokris area (Greece). J. Geochem. Explor. 2018, 194, 189-197. [CrossRef]

31. Economou-Eliopoulos, M.; Frei, R.; Megremi, I. Potential leaching of $\mathrm{Cr}(\mathrm{VI})$ from laterite mines and residues of metallurgical products (red mud and slag): An integrated approach. J. Geochem. Explor. 2016, 162, 40-49. [CrossRef]

32. Orphanoudakis, A.; Mposkos, E.; Kastritsis, I. A study of the mineralogical and geochemical composition of the Fe-Ni-laterite from the area of Paleochori (Grevena). Geol. Soc. Greece 1997, 31, 7-22.

33. Paraskevopoulos, G.; Economou, M. Genesis of magnetite ore occurrences by metasomatism of chromite ores in Greece. Neues. Jahrb. Mineral. Abh. 1980, 140, 29-53.

34. Michailidis, K.M. Zoned chromites with high Mn-contents in the Fe-Ni-Cr-laterite ore deposits from the Edessa area in Northern Greece. Miner. Depos. 1990, 25, 190-197. [CrossRef]

35. Marcopoulos, T.; Economou, M. Theophrastite, $\mathrm{Ni}(\mathrm{OH})_{2}$, a new mineral from northern Greece. Am. Mineral. 1981, 66, $1020-1021$.

36. Arnisalo, J.; Makela, K.; Bourgeois, B.; Spyropoulos, C.; Varoufakis, S.; Morten, E.; Maglaras, C.; Soininen, H.; Angelopoulos, A.; Eliopoulos, D.; et al. Integrated technologies for minerals exploration; pilot project for nickel ore deposits. Trans. Instn. Min. Metall. Sect. B Appl. Earth Sci. 1999, 108, B151-B163.

37. Laskou, M.; Economou, M. Palladium, Pt, Rh and Au Contents in Some Bauxite Occurrences of Greece. In Proceedings of the Balkan-Carpathian Congress, Sofia, Bulgaria, 11-13 December 1989; pp. 1367-1371.

38. Brindley, G.W.; Maksimović, Z. The nature and nomenclature of hydrous nickel-containing silicates. Clay Miner. 1974, 10, $271-277$. [CrossRef]

39. Glencore. Annual Report of Glencore Company Plc; Baar, Switzerland, 2019. Available online: https://www.glencore.com/dam/ jcr:ae4466b4-7ef4-4407-ae00-6ca55b694028/GLEN_2018_Resources_Reserves_Report-.pdf (accessed on 22 July 2020).

40. INSG. Nickel in the Balkan Region. Joint Study of the Copper, Lead, Zinc and Nickel Industries in the Balkan Region; International Nickel Studies Group; INSG: San Diego, CA, USA, 2015; p. 85.

41. Petavratzi, E.; Gunn, A.G.; Kresse, C.C. BGS, London, Commodity Review, 2019; 72 p. Available online: https://www.bgs.ac.uk/ mineralsuk/search/home.html (accessed on 13 September 2021).

42. Livingstone, A.; Bish, D.L. On the new mineral thoephrastite, a nickel hydroxide, from Unst, Shetland, Scotland. Mineral. Mag. 1982, 46, 1-5. [CrossRef]

43. Henry, D.A.; Birch, W.D. Otwayite and theophrastite from the Lord Brassey Mine, Tasmania. Mineral. Mag. 1992, 56, 252-255. [CrossRef]

44. Arai, S.; Ishimaru, S.; Miura, M.; Akizawa, N.; Mizukami, T. Post-Serpentinization Formation of Theophrastite-Zaratite by Heazlewoodite Desulfurization: An Implication for Shallow Behavior of Sulfur in a Subduction Complex. Minerals 2020, 10, 806. [CrossRef]

45. Economou-Eliopoulos, M. A new solid solution $\left[(\mathrm{Co}, \mathrm{Mn}, \mathrm{Ni})(\mathrm{OH})_{2}\right]$, in the Vermion $\mathrm{Mt}$ (Greece) and its genetic dignificance for the mineral group of hydroxides. In Chemical Mineralogy, Smelting and Metallization; McLaughlin, E.D., Braux, L.A., Eds.; Nova Science Publishers: New York, NY, USA, 2009.

46. Economou, M.; Marcopoulos, T. Genesis of the new mineral theophrastite, Ni(OH)2. Chem. Erde 1983, $42,53-56$.

47. Maksimovic, Z. Genesis of Mediterranean karstic bauxites and karstic nickel deposits. Bull. Acad. Serbe Sci. Arts 2010, 46, 1-27.

48. Williams-Jones, A.E.; Vasyukova, O.V. The Economic Geology of Scandium, the Runt of the Rare Earth Element Litter. Econ. Geol. 2018, 113, 973-988. [CrossRef]

49. Jaireth, S.; Hoatson, D.M.; Miezitis, Y. Geological setting and resources of the major rare-earth-element deposits in Australia. Ore Geol. Rev. 2014, 62, 72-128. [CrossRef]

50. Kim, J.; Azimi, G. An innovative process for extracting scandium from nickeliferous laterite ore: Carbothermic reduction followed by $\mathrm{NaOH}$ cracking. Hydrometallurgy 2020, 191, 105194. [CrossRef]

51. Augé, T.; Legendre, O. Pt-Fe nuggets from alluvial deposits in Eastern Madagascar. Can. Mineral. 1992, 30, 983-1004.

52. Ndjigui, P.D.; Bilong, P. Platinum-group elements in the serpentinite lateritic mantles of the Kongo-Nkamouna ultramafic massif (Lomié region, South-East Cameroon). J. Geochem. Explor. 2010, 107, 63-76. [CrossRef]

53. Gray, R.; Owen, D.; Adams, C. Accounting and Accountability: Changes and Challenges in Corporate Social and Environmental Reporting; Prentice-Hall: London, UK, 1996.

54. Maier, W.D.; Barnes, S.-J.; Bandyayera, D.; Livesey, T.; Li, C.; Ripley, E. Early Kibaran rift-related mafic-ultramafic magmatism in western Tanzania and Burundi: Petrogenesis and ore potential of the Kapalagulu and Musongati layered intrusions. Lithos 2008, 101, 24-53. [CrossRef]

55. Konstantopoulou, G.; Economou-Eliopoulos, M. Distribution of Platinun-Group Elements and Gold within the Vourinos chromitite ores, Greece. Econ. Geol. 1991, 86, 1672-1682. [CrossRef]

56. Aiglsperger, T.; Proenza, J.A.; Font-Bardia, M.; Baurier-Amat, S.; Gali, S.; Lewis, J.F.; Longo, F. Supergene neoformation of Pt-Ir-Fe-Ni alloys: Multistage grains explain nugget formation in Ni-laterites. Mineral. Depos. 2017, 52, 1069-1083. [CrossRef]

57. Aiglsperger, T.; Proenza, J.A.; Lewis, J.F.; Labrador, M.; Svojtka, M.; Rojas-Purón, A.; Longo, F.; Durišová, J. Critical metals (REE, Sc, PGE) in Ni laterites from Cuba and the Dominican Republic. Ore Geol. Rev. 2016, 73, 127-147. [CrossRef]

58. Bowles, J.F.W. The development of platinum-group minerals in laterites. Econ. Geol. 1986, 81, 1278-1285. [CrossRef] 
59. Bowles, J.F.W.; Gize, A.P.; Vaughan, D.J.; Norris, S.J. Organic controls on platinum group PGE solubility in soils: Initial data. Chron. Rech. Min. 1995, 520, 65-73.

60. Bowles, J.F.W.; Suárez, S.; Prichard, H.M.; Fisher, P.C. Weathering of PGE-sulfides and Pt-Fe alloys, in the Freetown Layered Complex, Sierra Leone. Miner. Depos. 2017, 52, 1127-1144. [CrossRef]

61. Grey, J.D.; Schorin, K.H.; Butt, C.R.M. Mineral associations of platinum and palladium in lateritic regolith, Ora Banda Sill, Western Australia. J. Geochem. Explor. 1996, 57, 245-255. [CrossRef]

62. Economou-Eliopoulos, M. Platinum-group element distribution in chromite ores from ophiolite complexes: Implications for their exploration. Ore Geol. Rev. 1996, 11, 363-381. [CrossRef]

63. Economou-Eliopoulos, M.; Frei, R.; Atsarou, C. Application of chromium stable isotopes to the evaluation of Cr (VI) contamination in groundwater and rock leachates from central Euboea and the Assopos basin (Greece). Catena 2014, 122, 216-228. [CrossRef]

64. Oze, C.; Bird, K.D.; Fendorf, S. Genesis of hexavalent chromium from natural sources in soil and groundwater. Proc. Natl. Acad. Sci. USA 2007, 104, 6544-6549. [CrossRef]

65. Economou-Eliopoulos, M.; Antivachi, D.; Vasilatos, C.; Megremi, I. Evaluation of the Cr(VI) and other toxic element contamination and their potential sources: The case of the Thiva basin (Greece). Geosci. Front. 2012, 3, 523-539. [CrossRef]

66. Ziwa, G.; Crane, R.; Hudson-Edwards, K.A. Geochemistry, Mineralogy and Microbiology of Cobalt in Mining-Affected Environments. Minerals 2021, 11, 22. [CrossRef]

67. Roberts, S.; Gunn, G. Cobalt. In Critical Metals Handbook; John Wiley \& Sons, Inc.: New York, NY, USA, $2014 ;$ pp. $122-149$.

68. Newsome, L.; Arguedas, A.S.; Coker, V.S.; Boothman, C.; Lloyd, J.R. Manganese and cobalt redox cycling in laterites; Biogeochemical and bioprocessing implications. Chem. Geol. 2020, 531, 119330. [CrossRef]

69. Megremi, I. Controlling Factors of the Mobility and Bioavailability of $\mathrm{Cr}$ and Other Metals at the Environment of Ni-Laterites. Ph.D. Thesis, University of Athens, Athens, Greece, 2010; p. 316.

70. Ettler, V. Soil contamination near non-ferrous metal smelters: A review. Appl. Geochem. 2016, 64, 56-74. [CrossRef]

71. Arruti, A.; Fernandez-Olmo, I.; Irabien, A. Evaluation of the contribution of local sources to trace metals levels in urban PM2.5 and PM10 in the Cantabria region (Northern Spain). J. Environ. Monit. 2010, 12, 1451-1458. [CrossRef]

72. World Health Organization (WHO). Guidelines for drinking water quality. In World Health Organization Geneva, 4th ed.; World Health Organization (WHO): Geneva, Switzerland, 2017.

73. USEPA. Literature Review of Contaminants in Livestock and Poultry Manure and Implications for Water Quality; USEPA: Washington, DC, USA, 2013.

74. Gamaletsos, P.N.; Godelitsas, A.; Filippidis, A.; Pontikes, Y. The Rare Earth Elements Potential of Greek Bauxite Active Mines in the Light of a Sustainable REE Demand. J. Sustain. Metall. 2019, 5, 20-47. [CrossRef]

75. Maksimovic, Z.J.; Pantó, G. Authigenic rare earth minerals in karst-bauxites and karstic nickel deposits. In Rare Earth Minerals, Chemistry, Origin and Ore Deposits; Jones, A.P., Wall, F., Williams, C.T., Eds.; The Mineralogical Society Series 7: Washington, DC, USA, 1996; Chapter 10; pp. 257-279.

76. Ohfuji, H.; Rickard, D. Experimental syntheses of framboids-a review. Earth Sci. Rev. 2005, 71, 147-170. [CrossRef]

77. Heim, C. An Integrated Approach to the Study of Biosignatures in Mineralizing Biofilms and Microbial Mats. Ph.D. Thesis, University of Göttingen, Göttingen, Germany, 2010; p. 175.

78. MacLean, L.C.W.; Pray, T.J.; Onstott, T.C.; Brodie, E.L.; Hazen, T.C.; Southam, G. Mineralogical, chemical and biological characterization of an anaerobic biofilm collected from a borehole in a deep gold mine in South Africa. J. Geomicrobiol. 2007, 24, 491-504. [CrossRef]

79. Hudson-Edwards, K.A.; Santini, J.M. Arsenic-Microbe-Mineral Interactions in Mining-Affected Environments. Minerals 2013, 3, 337-351. [CrossRef]

80. Haferburg, G.; Kothe, E. Microbes and metals: Interactions in the environment. J. Basic Microbiol. 2007, 47, 453-467. [CrossRef]

81. Pan, C.; Liu, H.; Catalano, J.G.; Qian, A.; Wang, Z.; Giammar, D.E. Rates of Cr(VI) generation from CrxFe1-x(OH)3 solids upon reaction with manganese oxide. Environ. Sci. Technol. 2007, 51, 12416-12423. [CrossRef]

82. Vithanage, M.; Kumarathilaka, P.; Oze, C.; Karunatilake, S.; Seneviratne, M.; Hseu, Z.Y.; Gunarathne, V.; Dassanayake, M.; Ok, Y.S.; Rinklebe, J. Occurrence and cycling of trace elements in ultramafic soils and their impacts on human health: A critical review. Environ. Int. 2019, 131, 104974. [CrossRef]

83. Laskou, M.; Economou-Eliopoulos, M. The role of micro-organisms on the mineralogical and geochemical characteristics of the Parnassos-Ghiona bauxite deposits, Greece. J. Geochem. Explor. 2007, 93, 67-77. [CrossRef]

84. Laskou, M.; Economou-Eliopoulos, M. Bio-mineralization and potential biogeochemical processes in bauxite deposits: Genetic and ore quality significance. Mineral. Petrol. 2013, 107, 471-486. [CrossRef]

85. Baskar, S.; Baskar, R.; Kaushik, A. Role of microorganisms in weathering of the Konkan-Goa laterite formation. Curr. Sci. 2003, 85, $1129-1134$.

86. Russell, M.J.; Hall, A.J.; Boyce, A.J.; Fallick, A.E. On hydrothermal convection systems and the emergence of life. Econ. Geol. 100th Anniv. Spec. 2005, 100, 419-438.

87. Southam, G.; Saunders, J.A. The geomicrobiology of ore deposits. Econ. Geol. 2005, 100, 1067-1084. [CrossRef]

88. Lovley, D.R.; Phillips, E.J.P. Availability of ferric iron for microbial reduction in bottom sediments of the freshwater tidal Potomac River. Appl. Environ. Microbiol. 1986, 52, 751-757. [CrossRef] [PubMed] 
89. Myers, C.R.; Nealson, K.H. Bacterial manganese reduction and growth with manganese oxide as the sole electron acceptor. Science 1988, 240, 1319-1321. [CrossRef] [PubMed]

90. Perez, J.; Jeffries, T.W. Roles of manganese and organic acid chelators in regulating lignin degradation and biosynthesis of peroxidases by Phanerochaete chrysosporium. Appl. Environ. Microbiol. 1992, 58, 2402-2409. [CrossRef]

91. Raptis, S.; Gasparatos, D.; Economou-Eliopoulos, M.; Petridis, A. Chromium uptake by lettuce as affected by the application of organic matter and $\mathrm{Cr}(\mathrm{VI})$-irrigation water: Implications to the land use and water management. Chemosphere 2018, 210, 597-606. [CrossRef] 